УДК $579.68: 579.873 .1$

\title{
DOI: https://www.doi.org/10.18524/978-617-689-454-4.3
}

\section{РОЗДІЛ 3. АКТИНОБАКТЕРІЇ ОДЕСЬКОЇ ЗАТОКИ ЧОРНОГО МОРЯ}

\section{Страшнова І.В., Коротаєва Н.В., Васильєва Н.Ю., Штеніков М.Д., Потапенко К.С., Лісютін Г.В., Чабан М.М., Гудзенко Т.В., Іваниця В.О.}

Одеський національний університет імені I.I. Мечникова, вул. Дворянська, 2, м. Одеса, 65082, Україна, тел. (0482) 6879 64, e-mail: fabiyanska@ukr.net

\section{Анотація}

У цьому розділі наведено результати виявлення актиноміцетів в біологічних обростаннях природного черепашнику, бетонних споруд і мідій Одеської затоки Чорного моря та описана таксономічна різноманітність і основні біологічні властивості 53 досліджених штамів. При рості на різних поживних середовищах виділені штами актиноміцетів утворюють субстратний і повітряний міцелії, демонструючи різноманіття морфологічних типів. Деякі штами утворюють водорозчинні і меланоїдні пігменти на відповідних середовищах. Ізольовані актиноміцети ростуть у температурному діапазоні $10{ }^{\circ} \mathrm{C}-45{ }^{\circ} \mathrm{C}$. Більшість штамів актиноміцетів добре ростуть у присутності $\mathrm{NaCl}$ у концентрації до 9\%. Досліджені штами утилізують різні запропоновані джерела вуглецю, демонструючи значну метаболічну активність. Найбільш вживаним субстратом для актиноміцетів із черепашнику є лактоза, для актиноміцетів із бетону - рамноза, для актиноміцетів із мідій - цукроза. Попередня ідентифікація за порівнянням спектрів жирних кислот дозволила встановити, що ізольовані штами актиноміцетів 3 різними індексами подібності відносяться до родів Streptomyces i Nocardiopsis, iз суттєвим домінуванням представників poду Streptomyces. У жирнокислотних спектрах досліджених актиноміцетів роду Streptomyces присутні ізомери розгалужених насичених i ненасичених жирних кислот із загальною кількістю атомів вуглецю від 10 до 17. Виявлення і виділення актиноміцетів із об'єктів Чорного моря сприятиме подальшому вивченню екологічної ролі цих бактерій в морському середовищі, їх різноманітності, розподілу, умов культи- 
вування, еволюційних механізмів пристосування до життя в морі та оцінці біотехнологічного потенціалу до продукції нових біологічно активних метаболітів.

Ключові слова: актиноміцети, біологічні властивості, Чорне море, Одеська затока, біологічні обростання

\section{Вступ}

Відділ Actinobacteria є одним із найбільших серед 30 основних відділів, які на даний момент визнаються в домені Bacteria. Цей відділ станом на 2016 р. включає 6 класів, 18 порядків, 14 підпорядків, 63 родини та 374 роди (http://www.bacterio. net/-classifphyla.html\#actinobacteria) [68].

Термін «актиноміцети» використовується для позначення представників порядку Actinomycetales відділу Actinobacteria. Представники актиноміцетів були охарактеризовані як найважливіша група мікроорганізмів у галузі біотехнології, оскільки вони $€$ продуцентами біоактивних вторинних метаболітів для медичного, промислового та сільськогосподарського застосування [9, 16, $54,62]$. Проте дотепер ідентифіковано та досліджено менше 1\% актиноміцетів [17].

Із 500000 природних сполук, отриманих з біологічних джерел, приблизно 70000 є продуктами мікробного синтезу, з яких $29 \%$ належить вторинним метаболітам актиноміцетів. Приблизно 60\% антибіотиків, які використовуються, були виділені з актиноміцетів між 1950 і 1970 роками, виключно з роду Streptomyces [17].

Однак виникаючі інфекційні захворювання та їх збудники, які характеризуються множинною лікарською стійкістю, стають основною загрозою глобальному здоров'ю $[43,57]$. Тому існує нагальна потреба в нових антибіотичних речовинах для боротьби з багатьма хворобами, в тому числі бактеріальними, вірусними, грибковими, раком, імунними системними розладами та ін. [21, $25,30,34]$.

В цьому аспекті перспективним джерелом для виділення мікроорганізмів, здатних продукувати нові активні вторинні метаболіти, є морське середовище $[14,38,48,58]$. Серед таких 
мікроорганізмів особливий інтерес викликають рідкісні актиноміцети, оскільки відомо, що вони продукують хімічно різноманітні сполуки з широким спектром біологічної активності $[26,27$, $51,60,67,68]$.

Морські актиноміцети привертають особливу увагу науковців в останні роки. У ранніх роботах описуються види родів Actinomyces, Nocardia, Nocardioides, Micromonospora i Streptomyces 3 морських відкладень [21, 77]. У значної частини цих актиноміцетів виявлено антибіотичну активність, що дозволяє припустити, що морське середовище може бути цікавим джерело для біорозвідки $[42,72,75,81]$. Однак існує не безпідставна думка, що морські актинобактерії потрапляють в море з суші і знаходяться там у вигляді метаболічно неактивних спор [18]. Тому вивчення вторинних метаболітів актинобактерій, виділених 3 моря, часто призводить до виявлення раніше відомих сполук, описаних як метаболіти наземних актиноміцетів [26]. Проте, за даними багатьох авторів, у автохтонних морських актинобактерій метаболіти 3 новими структурами виявляються досить часто $[9,28,50,66]$. Так, були описані морські актиноміцети родів Salinibacterium, Serinicoccus i Salinispora [32, 47, 83]. Представники деяких видів цих родів продукують унікальні сполуки, такі як саліноспораміди [29], які проходять клінічні випробування як протипухлинні агенти.

Велика кількість рідкісних актиноміцетів виділена із гідробіонтів, таких як губки, корали, медузи, мідії, риби, морські їжаки водорості, асцидії, актинії, морські огірки та ін. [23, 67, 73, 76].

Незважаючи на те, що актиноміцети можуть бути виділені із різних об'єктів морського середовища, чисельність їх там незначна і більшість із них погано ростуть на поживних середовищах в лабораторних умовах. Більше того, таксономічне положення майже половини колекції актинобактерій морського походження не можна визначити навіть до рівня роду, що підтверджує їх оригінальність [31, 45, 78].

Виявлення і виділення актиноміцетів із об'єктів Чорного моря, яке за еколого-геохімічними особливостями є унікальним, сприятиме вивченню екологічної ролі цих бактерій в морському середовищі, їх різноманітності, розподілу, умов культивування та 
еволюційних механізмів пристосування до життя в морі. Ці аспекти біології морських актиноміцетів повинні бути зрозумілі для того, щоб повніше оцінити їх біотехнологічний потенціал до продукції нових біологічно активних метаболітів [5].

\section{1. Методи дослідження}

Ізоляцію актиноміцетів проводили із зразків природного черепашнику i бетонних поверхонь, зібраних на глибині 0,2-1,0 м, а також із мушлі мідій, зібраних на глибині 5,0-6,0 м, у червні-липні 2020 р. в Одеській затоці Чорного моря в районі Гідробіологічної станції Одеського національного університету імені I.I. Мечникова (Одеса, Україна, 46²7'01'”N 3046'14'”E). Матеріалом для дослідження були проби біологічних обростань черепашнику і бетону, що представляли собою наліт із морських біологічних об'єктів і продуктів їх життєдіяльності. Зразки проб збирали шляхом зіскобу стерильним скальпелем біологічного обростання зазначених поверхонь та поміщали у стерильний посуд. Проби обростань черепашнику і бетону, і мушлі мідій поміщали в стерильну морську воду (100 мл) в колбах і гойдали на шейкері (фірми New Brunswick Innova $® 43$, Німеччина) при $28{ }^{\circ} \mathrm{C}$, 150 об/хв, 30 хв. Отримані суспензії в одному варіанті перед посівом прогрівали при температурі $50{ }^{\circ} \mathrm{C}$ впродовж 15 хв, в іншому - посів здійснювали без термічної обробки. Для посіву суспензії об'смом 0,1 мл рівномірно розподіляли по поверхні щільних поживних середовищ $[4,7]$.

Для ізоляції актиноміцетів використано такі поживні середовища: Гаузе 2, Чапека, Ешбі, крохмаль-аміачний і грунтовий агари [1]. Усі середовища готували на морській воді і добавляли антибіотик налідиксову кислоту у концентрації 10 мг/л для пригнічення росту супутньої мікробіоти. Посіви на усі середовища здійснювали у 3-х повторах. Інкубацію проводили при температурі $28{ }^{\circ} \mathrm{C}$ впродовж 14-21 доби.

Про наявність актиноміцетів у досліджуваних пробах свідчило утворення колоній з типовим міцелієм (субстратним і повітряним) або колоній, які мали складчасту поверхню. Також звертали увагу на пігментацію поживного середовища і колоній. 
Характерні для актиноміцетів колонії відсівали і субкультивували на середовищах Гаузе 2, вівсяному агарі (BA) і крохмаль-казеїновому агарі (ККА), доводячи до стану чистої культури. Інкубацію проводили при температурі $28{ }^{\circ} \mathrm{C}$ протягом 7-10 діб. Чисті ізоляти зберігали при температурі $4{ }^{\circ} \mathrm{C}$ до подальшого використання.

В отриманих ізолятів вивчали низку біологічних властивостей: морфологічні, фізіологічні, біохімічні та хемотаксономічні $[3,4,7]$. Зокрема, морфологію і характер росту досліджували на середовищах м'ясо-пептонний агар (МПА), Гаузе 1, Гаузе 2, ВА, KКА і на середовищах ISP (ISP-1-ISP-7), відповідно до Міжнародного проєкту Streptomyces (ISP) [63], протягом 14-21 доби при $28^{\circ} \mathrm{C}$.

Синтез меланоїдних пігментів досліджували на середовищах ISP-6 i ISP-7, культивуючи протягом 14-21 доби при $28{ }^{\circ} \mathrm{C}$.

Морфологію клітин вивчали шляхом мікроскопії фіксованих препаратів, забарвлених водним розчином фуксину (світловий мікроскоп Carl Zeizz Axio, програмне забезпечення Zen 2.3 lite, x1500).

Відношення до хлориду натрію $(\mathrm{NaCl})$ визначали на середовищі МПА, з різними концентраціями $\mathrm{NaCl}(1,0 ; 2,0 ; 5,0 ; 7,0 ; 9,0$; $12,0 ; 15,0 \% \%)$. Інкубацію проводили впродовж 14 діб при $28{ }^{\circ} \mathrm{C}$. Наявність росту реєстрували візуально, оцінюючи як «гарний», «слабкий» чи «відсутність росту» [1].

Утилізацію джерел вуглецю досліджували на мінімальному середовищі ISP 9. Джерелами вуглецю були глюкоза, фруктоза, галактоза, гліцерол, лактоза, ксилоза, рамноза, манітол, сорбітол, маноза, арабіноза та цукроза, які додавали окремо до розплавленого мінімального середовища, що не містило вуглеводів, для отримання кінцевої концентрації $1 \%$ і розливали в стерильні чашки Петрі. Після застигання середовищ здійснювали посів досліджуваних ізолятів. Інкубацію проводили протягом 14-21 доби при $28^{\circ} \mathrm{C}$. Ріст штамів оцінювали як «гарний», «слабкий» чи «відсутність росту» $[2,11]$.

Визначення складу клітинних ліпідів проводили згідно MIS Operating Manual $[53,59]$ з використанням газового хроматографa Agilent 7890 (Agilent Technologies, США), капілярної колонки 
ULTRA 2 (25 м х 0,2 мм х 0,33 мкм) і полум'яно-іонізаційного детектора. Для порівняльного аналізу спектрів жирних кислот за допомогою автоматичної системи ідентифікації Sherlock Microbia IIdentification System (MIDI Sherlock version 6.2, MIDI Library ACTIN 3.80) [59] актиноміцети вирощували у 20 мл середовища Triptic soy broth (Merck, Німеччина), струшуючи на шейкері при $28{ }^{\circ} \mathrm{C}, 150$ об/хв упродовж 3 діб. Після цього бульйонні культури фільтрували (діаметр пор фільтрів 0,45 мкм). Приблизно 40 мг відділеної біомаси клітин кожного штаму переносили в скляні віали для екстракції жирних кислот. Виділення та хроматографічне розділення жирних кислот здійснювали згідно стандартного протоколу. Для лізису клітин та омилення ліпідів клітин актиноміцетів використовували 1 мл суміші $1,125 \mathrm{M}$ розчину $\mathrm{NaOH}$ у метанолі при температурі 95-100 ${ }^{\circ} \mathrm{C}$ впродовж 30 хв. Подальше метилування жирних кислот здійснювали додаванням кислого розчину 2 мл $6.0 \mathrm{~N} \mathrm{HCl}$ у метанолі при $80^{\circ} \mathrm{C}$ впродовж 10 хв. Екстраговані метилові ефіри жирних кислот нейтралізували 0,3 М розчином $\mathrm{NaOH}$ [59]. Потім для проведення хроматографічного аналізу пробу у кількості 2 мкл вводили в режимі split з коефіцієнтом 40:1, температура випаровувача $250{ }^{\circ} \mathrm{C}$. Розділення проводили в режимі програмування температури: початкова температура $170{ }^{\circ} \mathrm{C}$ з наступним градієнтом $5{ }^{\circ} \mathrm{C} /$ хв до $270{ }^{\circ} \mathrm{C}$. Вміст жирних кислот виражали у відсотках до загальної суми площ піків. Після цього проводили ідентифікацію досліджуваних штамів [59].

Статистичний аналіз складу жирних кислот проводився з використанням програмного забезпечення MIDI Library Generation System (Microbial ID, Inc., Newark, Del.). Ця програма використовує двовимірний кластерний аналіз. Спорідненість виражається в евклідовій відстані (EDs), як відстань у двовимірному просторі [10].

\section{2. Морфологічна характеристика актинобактерій}

Із обростань черепашнику було виділено 20 ( $\mathrm{Lim} 2.1, \mathrm{Lim}$ 2.2 ... Lim 12.3), а із обростань бетонних поверхонь 19 (Conc 19, Conc 20 ... Conc 44) ізолятів актинобактерій [7]. У свою чергу, із проб мідій виділено 14 актиноміцетних ізоляти (Myt 1, Myt 2 ... Myt 12b) [4]. 
У всіх випадках для ізоляції актиноміцетів із морських об'єктів найкращим середовищем із використаних виявилося органічне середовище Гаузе 2. На цьому середовищі спостерігали найбільшу кількість і різноманітність колоній актиноміцетів. При посівах зразків проб на щільні середовища Чапека, Ешбі, крохмаль-аміачний і грунтовий агари актиноміцети росли погано (на чашках виявлялися поодинокі колонії).

Після отримання чистих культур, завдяки декілька разовим пересівам на м'ясо-пептонний агар (МПА), вівсяний агар (ВА), Гаузе 2 і крохмаль-казеїновий агар (ККА), вивчено культурально-морфологічні властивості виділених ізолятів. У наукових працях багатьох дослідників відмічається, що актиноміцети при рості на поживних середовищах демонструють значну різноманітність структурних характеристик колоній $[19,41,51]$. Винятком не стали й актинобактерії, виділені із Чорного моря. Ізольованим культурам притаманна здатність утворювати різноманітні колонії при рості на різних поживних середовищах. Ця властивість залежить і від складу середовищ і віку культур, а також зумовлена плеоморфізмом, (включаючи морфологічну варіабельність) видів актиноміцетів, у тому числі гетерогенністю популяції в середині одного виду.

На рисунках 3.1 і 3.2 продемонстровано відмінності в морфологічних ознаках колоній актиноміцетів штамів Lim 7.1 i Myt 7ch на різних за складом поживних середовищах.

В таблиці 3.1, як приклад, наведено ознаки колоній штамів $\operatorname{Lim} 3.3$ i Conc 42, виділених із обростань черепашнику і бетонних поверхонь, відповідно, і штаму Муt 7ch, виділеного із мушлі мідій.

Потрібно зауважити, що колонії деяких штамів, які утворили субстратний міцелій, легко знімаються з поживних середовищ, інші - міцно вростають в агаризоване середовище.

Отримані результати дослідження морфологічних ознак колоній актиноміцетів, виділених із чорноморських об'єктів [4, 7], підтверджують дані інших науковців щодо морфологічної варіабельності колоній актинобактерій, ізольованих із різних джерел. Tак, Yanti et al. [82] зазначають, що актиноміцети, виділені з мангрового осаду, ростуть на середовищах різного складу, утворюю- 


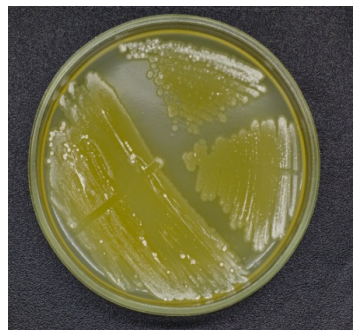

a)

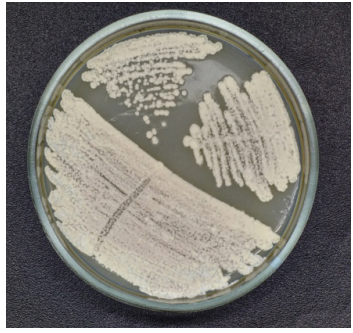

б)

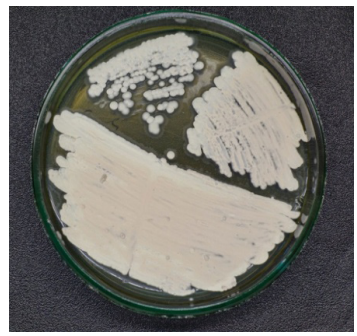

B)

Рис. 3.1. Колонії актинобактерій штаму Lim 7.1 на:

а) вівсяному агарі, б) ККА, в) МПА
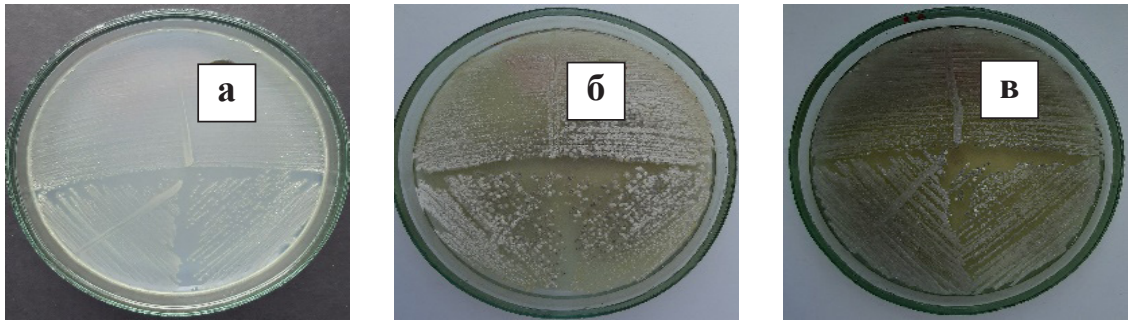

Рис. 3.2. Колонії актинобактерій штаму Мyt 7ch на: а) вівсяному агарі, б) ККА, в) Гаузе 2

чи різноманітні колонії, що відрізняються повітряним міцелієм, краєм і висотою субстратного міцелію, кольором зрілої спори, наявністю ексудату, пігментами та текстурою колоній [82]. Про плеоморфізм актинобактерій мова йде і в повідомленні Jayashanth [39], в якому автор детально описує морфологічні варіанти різних представників актинобактерій. Maria et al. [51] пишуть про різноманітність субстратного і повітряного міцелію актиноміцетів, виділених із зразків грунту, при рості на різних за складом середовищах, у тому числі і на середовищах ISP [39, 51].

При досліджені особливостей росту і морфології колоній чорноморських актиноміцетів із використанням середовищ ISP відмічено ріст переважної більшості усіх виділених штамів. Зокрема, майже усі штами актиноміцетів, ізольованих з обростань черепашнику, росли на використаних середовищах (табл. 3.2). 
Таблиця 3.1

Ознаки морфології колоній ізольованих актинобактерій

\begin{tabular}{|c|c|c|c|}
\hline Середовище & Штам Lim3.3 & Штам Conc 42 & Штам Муt 7ch \\
\hline МПА & $\begin{array}{c}\text { Бежеві колонії з } \\
\text { білувато-бежевим } \\
\text { повітряним } \\
\text { міцелієм }\end{array}$ & $\begin{array}{c}\text { Колонії бежевого } \\
\text { кольору із темно } \\
\text { сірим повітряним } \\
\text { міцелієм }\end{array}$ & \begin{tabular}{|c|} 
Округлі, \\
жовтувато- \\
бежеві колонії, iз \\
білимповітряним \\
міцелісм
\end{tabular} \\
\hline BA & $\begin{array}{c}\text { Темно- } \\
\text { бежевіколоніїз } \\
\text { коричневою } \\
\text { пігментацією } \\
\text { колонійі } \\
\text { середовища } \\
\end{array}$ & $\begin{array}{c}\text { Колонії світло } \\
\text { бежевого кольору } \\
\text { із темно сірим } \\
\text { повітряним } \\
\text { міцелієм }\end{array}$ & $\begin{array}{c}\text { Округлі, не } \\
\text { пігментовані } \\
\text { колонії із білим } \\
\text { повітряним } \\
\text { міцелієм }\end{array}$ \\
\hline Гаузе 2 & $\begin{array}{c}\text { Світло-бежеві } \\
\text { колонії з } \\
\text { білувато-бежевим } \\
\text { повітряним } \\
\text { міцелієм }\end{array}$ & $\begin{array}{c}\text { Колонії темно } \\
\text { бежевого кольору } \\
\text { із темно сірим } \\
\text { повітряним } \\
\text { міцелієм }\end{array}$ & \begin{tabular}{|c|} 
Округлі, жовті \\
колонії, із \\
білимповітряним \\
міцелієм
\end{tabular} \\
\hline ККА & $\begin{array}{c}\text { Темно-бежеві } \\
\text { колонії з сіруватою } \\
\text { пігментацією } \\
\text { повітряного } \\
\text { міцелію }\end{array}$ & $\begin{array}{c}\text { Колонії темно } \\
\text { коричневого } \\
\text { кольору із темно } \\
\text { сірим повітряним } \\
\text { міцелієм }\end{array}$ & $\begin{array}{c}\text { Округлі, жовтуваті } \\
\text { колонії із білим } \\
\text { повітряним } \\
\text { міцелієм }\end{array}$ \\
\hline
\end{tabular}

Однак деякі штами виявились досить вибагливими, а саме штами Lim 7.1 та Lim 7.2, ріст яких на середовищах ISP-1, ISP-2 i ISP-3 був бідним та спостерігався із затримкою, незважаючи на те, що ці середовища $є$ повноцінними і рекомендуються для культивування актиноміцетів $[51,55]$. Цей факт свідчить про те, що специфічні умови морського середовища впливають на фізіологію актинобактерій [7]. Водночас, на базовому середовищі ISP-9 досить активний ріст реєстрували для всіх штамів крім Lim 7.1 (рис. 3.3). Найменш придатним для росту усіх штамів із обростань черепашнику виявилося середовище ISP-6, одними із компонентів якого $є$ цитрат амонію заліза та тіосульфат натрію.

Ha ISP середовищах спостерігали різнокольорову пігментацію субстратного міцелію, формування та пігментацію повітряного міцелію, а також здатність виділених штамів синтезувати ме- 
Таблиця 3.2

Характеристика росту штамів актинобактерій, ізольованих із обростань черепашнику на середовищах ISP

\begin{tabular}{|c|c|c|c|c|c|c|c|c|}
\hline Штам & ISP-1 & ISP-2 & ISP-3 & ISP-4 & ISP-5 & ISP-6 & ISP-7 & ISP-9 \\
\hline $\operatorname{Lim} 2.1$ & + & + & + & + & + & - & + & $+*$ \\
\hline $\operatorname{Lim} 2.2$ & + & + & \pm & + & + & - & + & + \\
\hline $\operatorname{Lim} 3.1$ & $+*$ & $+*$ & $+*$ & $+*$ & + & $+* *$ & + & + \\
\hline $\operatorname{Lim} 3.2$ & $+*$ & $+*$ & $+*$ & $+*$ & + & - & + & + \\
\hline $\operatorname{Lim} 3.3$ & $+*$ & $+*$ & $+*$ & $+*$ & + & + & + & + \\
\hline $\operatorname{Lim} 3.4$ & $+*$ & $+*$ & $+*$ & $+*$ & + & $+* *$ & + & + \\
\hline $\operatorname{Lim} 4$ & + & + & \pm & + & + & - & + & + \\
\hline $\operatorname{Lim} 5.1$ & + & + & + & + & + & + & + & + \\
\hline $\operatorname{Lim} 5.2$ & + & + & + & + & + & + & + & + \\
\hline $\operatorname{Lim} 6.1$ & + & + & + & + & + & \pm & + & + \\
\hline $\operatorname{Lim} 6.2$ & + & + & + & + & + & + & + & + \\
\hline $\operatorname{Lim} 7.1$ & \pm & \pm & \pm & + & + & - & + & - \\
\hline $\operatorname{Lim} 7.2$ & + & \pm & \pm & + & + & - & + & + \\
\hline $\operatorname{Lim} 9.1$ & + & + & + & + & + & - & + & + \\
\hline $\operatorname{Lim} 9.2$ & $+*$ & + & + & + & + & + & + & + \\
\hline $\operatorname{Lim} 10$ & + & + & + & + & + & + & + & + \\
\hline $\operatorname{Lim} 12.1$ & + & + & + & + & + & - & + & + \\
\hline $\operatorname{Lim} 12.2$ & $+*$ & $+*$ & + & + & + & $+* *$ & + & + \\
\hline $\operatorname{Lim} 12.3$ & + & $+*$ & $+*$ & + & + & - & + & + \\
\hline $\operatorname{Lim} 56$ & + & + & + & + & + & - & + & + \\
\hline
\end{tabular}

Примітка: «+» - наявність щільного росту; «+» - слабкий ріст; «-» - відсутність росту; * - здатність утворювати водорозчинний пігмент; ** - здатність утворювати меланоїдні пігменти. 


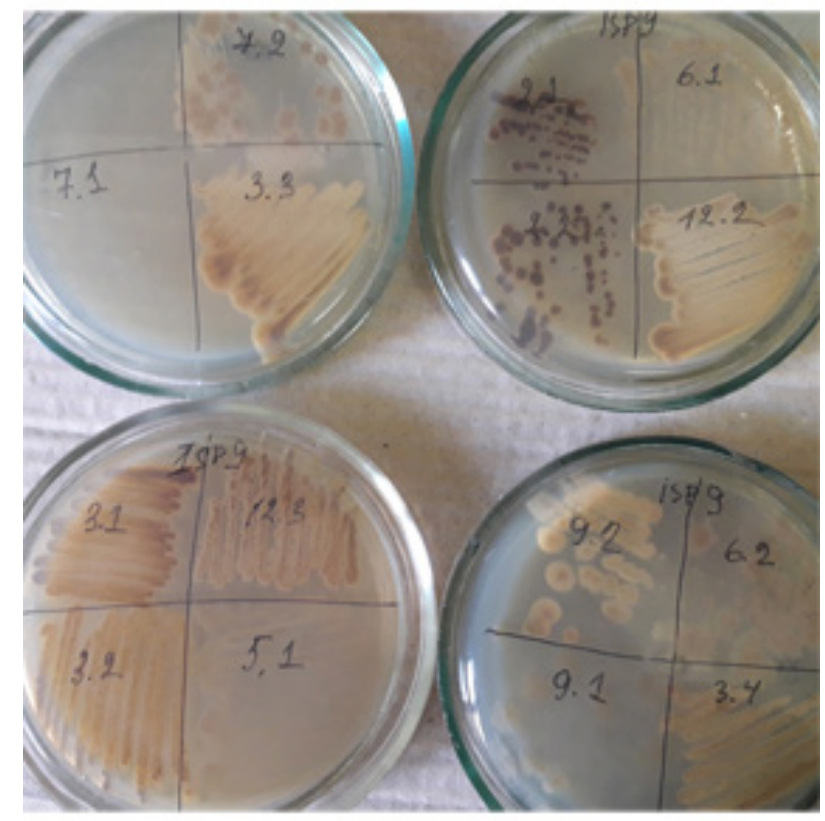

\section{Рис. 3.3. Фотографії субстратного міцелію штамів актинобактерій, ізольованих із обростань черепашнику, при рості на середовищі ISP-9 через 21 добу культивування}

ланоїдні пігменти, які визначали на пептон-дріжджовому середовищі з залізом (ISP-6) і тирозиновому агарі (ISP-7). Наприклад, штами $\operatorname{Lim} 3.1, \operatorname{Lim} 3.2, \operatorname{Lim} 3.3$ та $\operatorname{Lim} 3.4$ характеризувались як пігментацією повітряного міцелію, так і продукцією водорозчинних пігментів від темно-бежевого до темно-коричневого кольору за культивування на середовищах ISP-1, ISP-2, ISP-3 та ISP-4. Для штамів $\operatorname{Lim} 9.2, \operatorname{Lim} 12.2$ та Lim 12.3 відмічено утворення водорозчинних пігментів лише на окремих середовищах. Загалом $35,0 \%$ штамів, виділених із обростань черепашнику, синтезують водорозчинні пігменти.

У цей же час, синтез меланоїдних пігментів чорного кольору на середовищі ISP-6 реєстрували лише для штамів Lim 3.1, $\operatorname{Lim} 3.4$ та $\operatorname{Lim} 12.2$, що складає 15,0\% від усіх штамів, ізольованих із черепашнику [7]. Меланіни - це складні природні пігменти, що синтезуються тваринами, рослинами і мікроорганізмами. Вва- 
жається, що функція меланіну в мікробах пов'язана із захистом від впливу навколишнього середовища. Наприклад, бактерії, що продукують меланіни, стійкіші до антибіотиків [46], а меланіни в грибах беруть участь у грибковому патогенезі рослин [22].

Сполуки меланіну - це нерегулярні темно-коричневі полімери, які утворюються різними мікроорганізмами шляхом ферментативного окиснення, вони захищають від електромагнітного випромінювання та володіють антиоксидантними властивостями і можуть ефективно захищати живі організми від різних антропогенних факторів та ультрафіолетового випромінювання [24, 49]. Морські актинобактерії також синтезують і виділяють темні пігменти, меланіни або меланоїди, які, окрім зазначених властивостей, вважаються корисними таксономічними критеріями $[13,50]$.

Варто зазначити, що більшість штамів не росли на середовищі ISP-6 - Lim 2.1, $\operatorname{Lim} 2.2, \operatorname{Lim} 3.2, \operatorname{Lim} 4, \operatorname{Lim} 7.1, \operatorname{Lim} 7.2, \operatorname{Lim}$ 9.1, $\operatorname{Lim} 9.2$ 12.1 та Lim 12.3. На противагу цьому, усі штами росли на середовищі ISP-7, але не продукували меланоїдні пігменти.

Для штамів, ізольованих 3 обростань бетону, характерна більш темна пігментація субстратного міцелію на середовищах ISP [7]. Здатність до формування водорозчинних пігментів відмічена для штамів Conc 27.1, Conc 36, Conc 41, Conc 42 та Conc 43, що складає 26,3\% від усіх штамів. Усі штами із обростань бетону не росли на середовищі ISP-6 і росли на ISP-7, але меланоїдні пігменти не синтезували (табл. 3.3).

Виявлення меланоїдних пігментів у штамів актинобактерій, виділених із мушлі мідій, показало, що лише 3 штами (Myt 2, Myt 6 та Myt 7ch) iз 14 здатні продукувати меланіни, при чому бактерії штаму Myt 6 синтезують меланоїди, які дифундують в обидва середовища (рис. 3.4), а бактерії штамів Myt 2 i Myt 7ch продукують пігменти лише на середовищі ISP-6 [4].

Морфологію клітин виділених актиноміцетів визначали, проводячи мікроскопію фіксованих препаратів, забарвлених фуксином. Слід зауважити, що морфологічна варіабельність властива не тільки колоніям актиноміцетів, клітини цих бактерій також схильні до різноманітності. На рисунку 3.5 наведено приклади клітин актинобактерій штамів Lim 3.3 i Lim 7.2, виділених із обростань черепашнику, і штамів Myt 5 i Myt 12a - із мідій. 
Таблиця 3.3

Характеристика росту штамів актинобактерій, ізольованих із обростань бетону на середовищах ISP

\begin{tabular}{|c|c|c|c|c|c|c|c|c|}
\hline Штам & ISP-1 & ISP-2 & ISP-3 & ISP-4 & ISP-5 & ISP-6 & ISP-7 & ISP-9 \\
\hline Conc 19 & + & + & + & + & + & - & + & + \\
\hline Conc 20 & + & + & + & + & + & - & + & + \\
\hline Conc 21 & + & + & + & + & + & - & + & + \\
\hline Conc 22 & + & + & + & + & + & - & + & + \\
\hline Conc 24 & + & + & + & + & + & - & + & + \\
\hline Conc 26 & + & + & + & + & + & - & + & + \\
\hline Conc 27.1 & $+*$ & $+*$ & $+*$ & $+*$ & + & - & + & + \\
\hline Conc 27.2 & + & + & + & + & + & - & + & + \\
\hline Conc 28.2 & + & + & + & + & + & - & + & + \\
\hline Conc 29 & + & + & + & + & + & - & + & + \\
\hline Conc 30 & + & + & + & + & + & - & + & + \\
\hline Conc 32 & + & + & + & + & + & - & + & + \\
\hline Conc 36 & $+*$ & $+*$ & $+*$ & $+*$ & + & - & + & + \\
\hline Conc 37 & + & + & + & + & + & - & + & + \\
\hline Conc 38 & + & + & + & + & + & - & + & + \\
\hline Conc 41 & $+*$ & $+*$ & $+*$ & $+*$ & + & - & + & + \\
\hline Conc 42 & $+*$ & $+*$ & $+*$ & $+*$ & + & - & + & + \\
\hline Conc 43 & $+*$ & $+*$ & $+*$ & $+*$ & + & - & + & + \\
\hline Conc 44 & + & + & + & + & + & - & + & + \\
\hline
\end{tabular}

Примітка: «+» - наявність щільного росту; «-» - відсутність росту; * - здатність утворювати водорозчинний пігмент. 


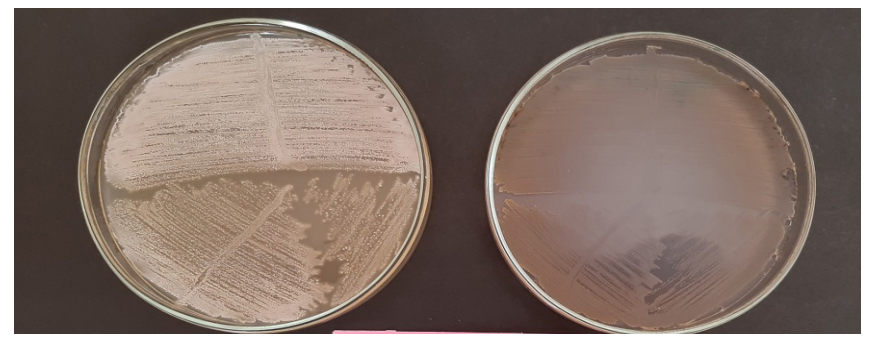

a)

б)

Рис. 3.4. Меланоїдні пігменти штаму Муt 6 на середовищах a) ISP-6, б) ISP-7

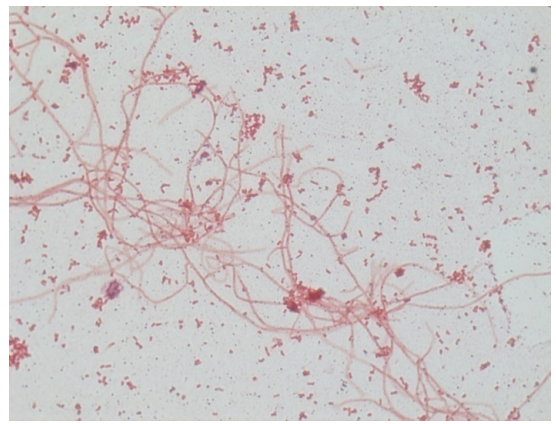

$\operatorname{Lim} 3.3$

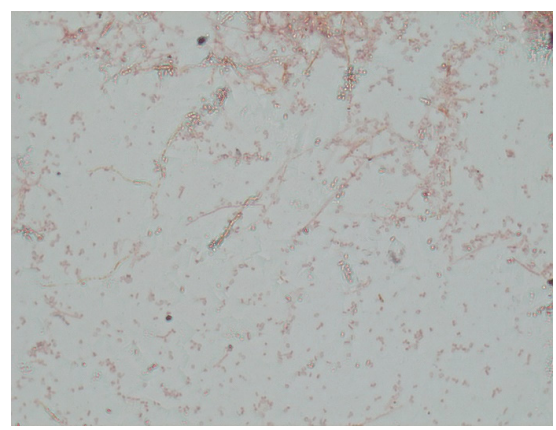

Myt 5

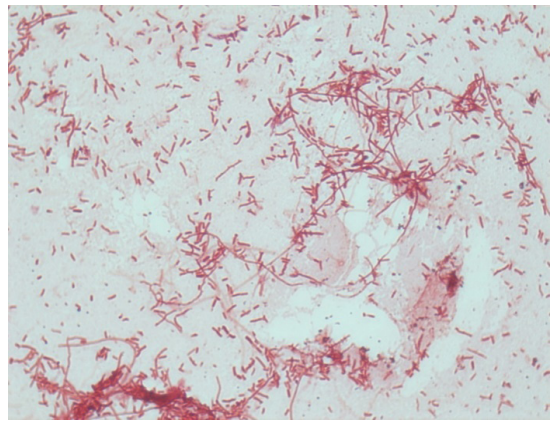

$\operatorname{Lim} 7.2$

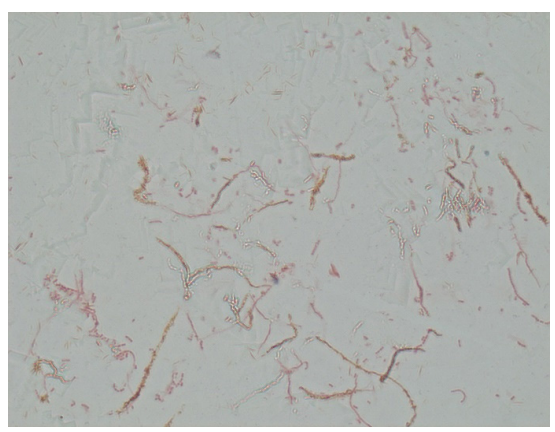

Myt 12a

Рис. 3.5. Морфологія клітин актинобактерій штамів Lim 3.3, Lim 7.2, Мyt 5 i Myt 12a (світловий мікроскоп Carl Zeizz Axio, програмне забезпечення Zen 2.3 lite, $\mathbf{x 1 5 0 0 )}$ 
Клітини більшості актинобактерій у препаратах представлені короткими паличками невеликих розмірів, розташованих поодинці, парами у ланцюжках, V-подібно, хаотично. Окрім того, поряд з короткими паличками зустрічались ниткоподібні клітини. Клітини деяких досліджених штамів були у вигляді кокоподібних форм. У препаратах одночасно могли спостерігати різні форми клітин: від кокоподібних до нитчастих $[4,7]$.

\section{3. Фізіолого-біохімічні властивості актинобактерій}

Оптимальний температурний діапазон росту виділених штамів актиноміцетів був у межах від 25 до $37^{\circ} \mathrm{C}$. У цих температурних межах ростуть усі досліджені штами (рис. 3.6-3.8). Більшість штамів (більше 60,0\%) із різних джерел виділення гарно росли і при температурі $45^{\circ} \mathrm{C}$. Зауважимо, що 80,0\% штамів актиноміцетів, виділених із обростань черепашнику і мідій, демонстрували гарний ріст при $10{ }^{\circ} \mathrm{C}$. При цьому температурному режимі гарно росли менше 60,0\% штамів із бетону.

3 урахуванням того, що досліджувані актинобактерії ізольовані з морського середовища, доречним було дослідити їх відношення до різних концентрацій хлориду натрію, що є однією із фізіологічних ознак, які характеризують актиноміцети. Здебільшо-

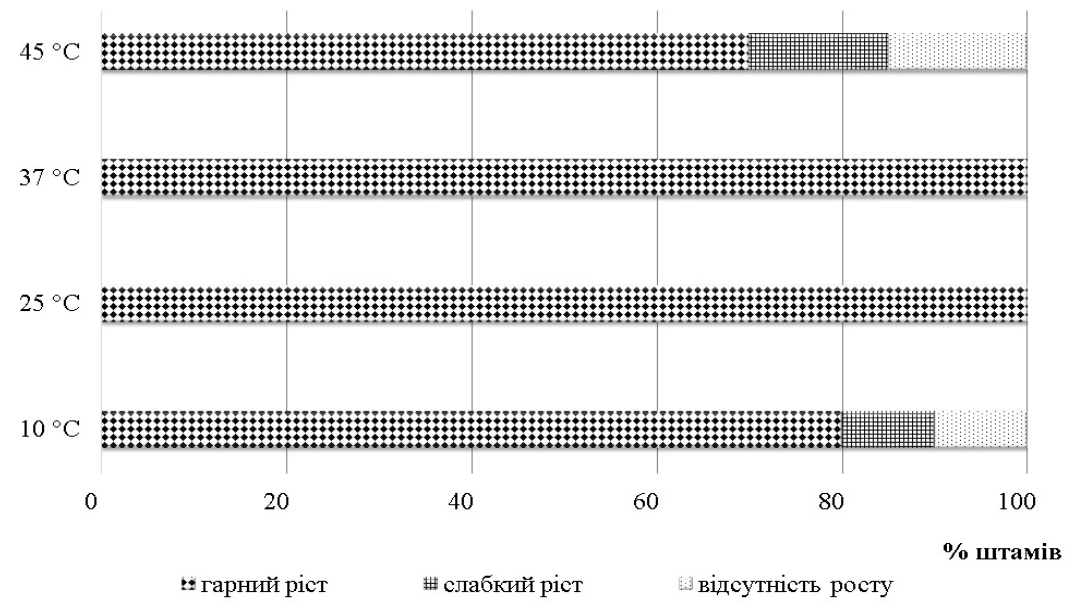

Рис. 3.6. Частка штамів актинобактерій, ізольованих із обростань черепашнику, здатних рости за різних температур 


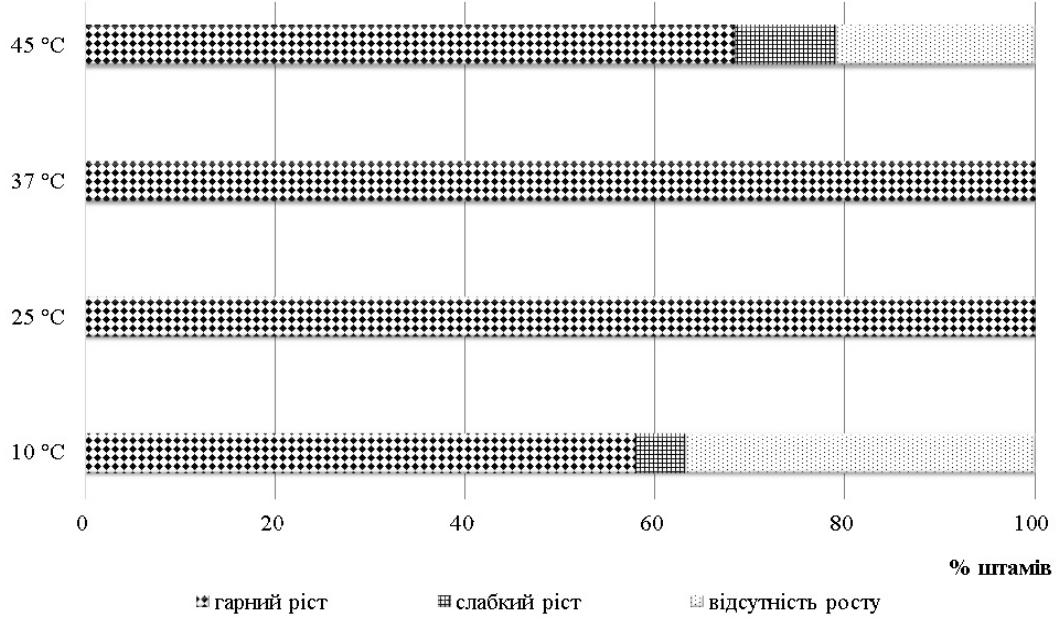

Рис. 3.7. Частка штамів актинобактерій, ізольованих із обростань бетону, здатних рости за різних температур

$45^{\circ} \mathrm{C}$

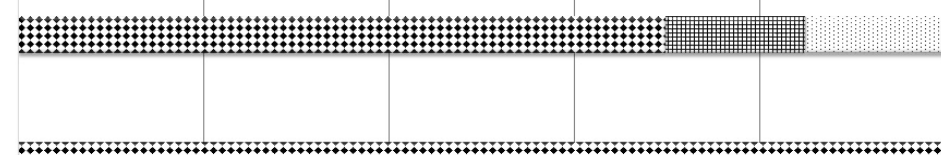

$37^{\circ} \mathrm{C}$

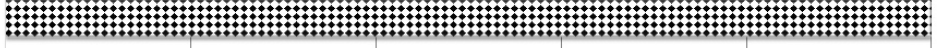

$25^{\circ} \mathrm{C}$

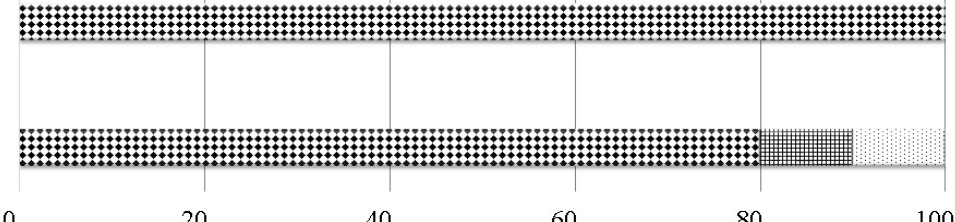

0

20

40

60

80

Рис. 3.8. Частка штамів актинобактерій, ізольованих із мідій, здатних рости за різних температур 
го стійкість до $\mathrm{NaCl}$ притаманна актинобактеріям, які мешкають в морських екосистемах і може розглядатись як непрямий доказ їх автохтонного морського походження [36, 37, 40, 80].Результати, отримані при визначенні відношення виділених актинобактерій до хлориду натрію, наведено на рис. 3.9-3.11.

Ізольовані актинобактерії росли при граничній концентрації $\mathrm{NaCl}$ 12,0\%. При такій концентрації фіксували ріст 20,0\% штамів, ізольованих із черепашнику і 26,5\% штамів, ізольованих з бетонних споруд. Цілком ймовірно, що ці штами є автохтонними і морське середовище є для них природним середовищем існування, хоча можливим $є$ і те, що дані актиноміцети в морі можуть бути i алохтонними, тобто привнесеними з суходолу, і перебувають там, зберігаючи свою життєздатність у вигляді спор [4, 7]. Наші міркування і припущення підтверджуються й іншими дослідниками. Так, наприклад, у роботі Antony-Babu et al. [12] йдеться про те, що види Streptomyces мають космополітичне розповсюдження, оскільки вони утворюють безліч спор, які легко диспергуються, а в публікації Anderson and Wellington [11] обговорюється, що ці нитчасті бактерії добре адаптовані до морського середовища [11,

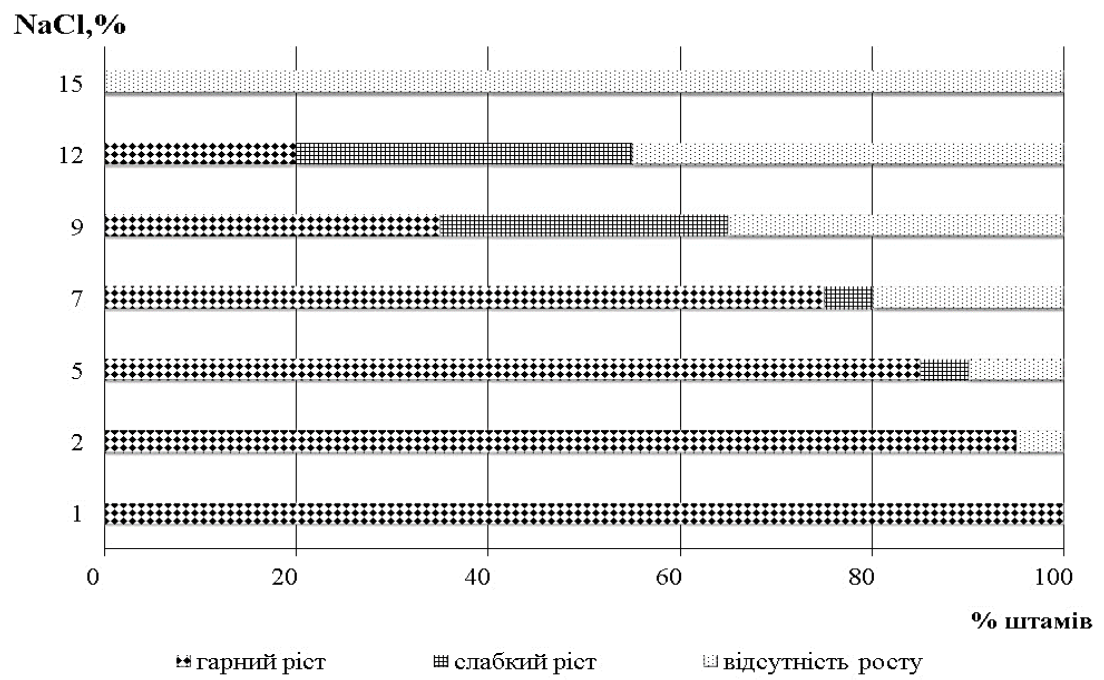

Рис. 3.9. Частка штамів актинобактерій, ізольованих із обростань черепашнику, толерантних до різних концентрацій $\mathrm{NaCl}$ 


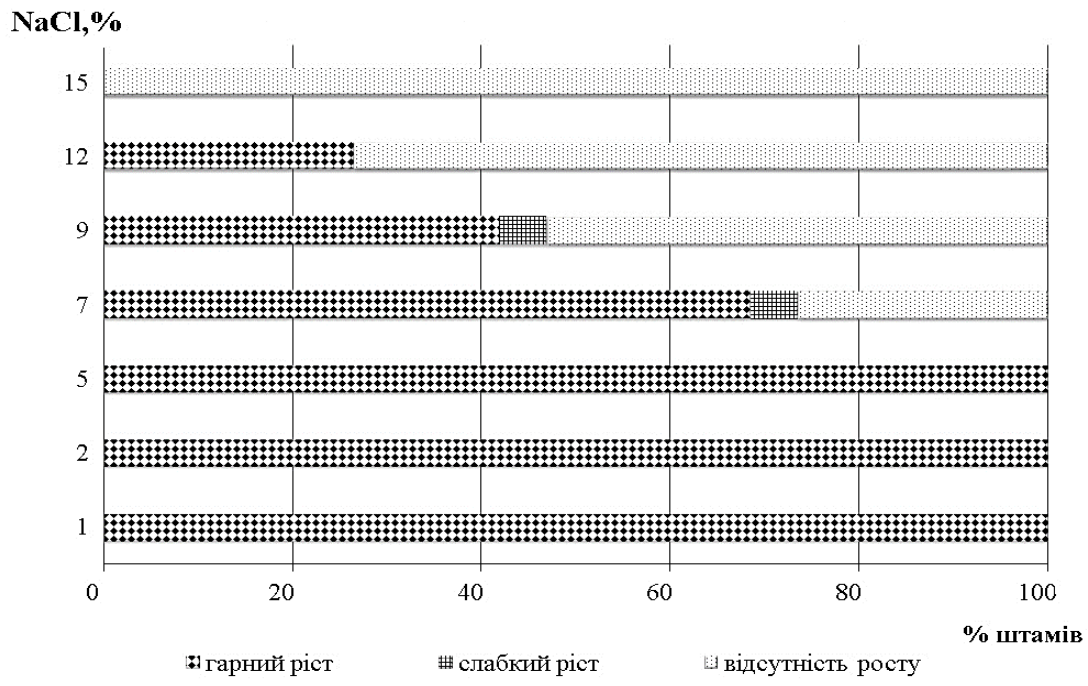

Рис. 3.10. Частка штамів актинобактерій, ізольованих із обростань бетону, толерантних до різних концентрацій $\mathrm{NaCl}$

$\mathrm{NaCl}, \%$

15

12

9

纤:t:t:t:t:t:t:t:t:t:t:

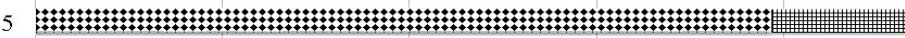

2

0

20

40

60

80

100

: гарний ріст

\# слабкий ріст

відсутність росту

$\%$ штамів

Рис. 3.11. Частка штамів актинобактерій, ізольованих із мідій, толерантних до різних концентрацій $\mathrm{NaCl}$ 
12]. Про виділення актинобактерій із різноманітних екстремальних ніш йдеться у публікаціях й інших авторів [35, 61].

При додаванні 5,0\% $\mathrm{NaCl}$ гарний ріст демонстрували 85,0\% штамів, ізольованих з обростань черепашнику, і 100,0\% штамів, ізольованих з бетону; при додаванні 7,0\% $\mathrm{NaCl}$, відповідно, 75,0\% i 68,5\%; при додаванні 9,0\% NaCl гарний ріст відмічено для 35,0\% штамів із черепашнику і 42,0\% штамів із бетону. Найменш стійкими до $\mathrm{NaCl}$ виявились штами Lim 9.1 та Lim 9.2.

Штами актинобактерій, ізольовані з мідій, виявилися більш чутливими до хлориду натрію. Для них гранична концентрація $\mathrm{NaCl}$ - 7\%. При такій концентрації спостерігався ріст 48,2\% виділених штамів. При додаванні у середовище $2 \% \mathrm{NaCl}$ гарний ріст демонстрували усі штами, 5\% - 85,0\%. Найменш стійкими до хлориду натрію виявились штами Myt 1, Myt 12a i Myt $12 \mathrm{~b}$.

За типом харчування актиноміцети є гетеротрофами (хемоорганотрофами). Для багатьох актиноміцетів, наприклад для представників роду Streptomyces, характерна олігокарбофілія, вони можуть рости на середовищах 3 низьким вмістом поживних речовин, що свідчить про їх можливість концентрувати поживні речовини. Для них відзначається наявність метаболічних шляхів та ферментних систем, рідкісних для інших мікроорганізмів [15, $49,56,65]$.

У проведених дослідженнях встановлено, що виділені штами актиноміцетів здатні залучати у свій метаболізм різні джерела вуглецю $[4,7]$. Усі використані вуглецеві субстрати споживалися бактеріями із черепашнику та із бетонних споруд (рис. 3.12-3.14).

За результатами проведених досліджень максимальна кількість штамів (85,0-95,0\%), ізольованих із обростань черепашнику, росте, використовуючи для конструктивного і енергетичного метаболізму лактозу, глюкозу, гліцерол, галактозу та рамнозу. Здатність рости у присутності ксилози продемонстрували лише 35,0\% штамів.

Виходячи $з$ отриманих даних, найкращим вуглецевим субстратом для виділених актиноміцетів була лактоза. За спроможністю бути метаболізованими актинобактеріями із черепашнику джерела вуглецю можна розташувати у такому порядку (від найспоживанішого до найменш придатного): лактоза > глюкоза > 
гліцерол/галактоза/рамноза > цукроза/манноза/манітол/сорбітол $>$ арабіноза $>$ фруктоза $>$ ксилоза.

Для штамів, ізольованих із обростань бетону, максимально сприятливим вуглеводом для росту виявилась рамноза $-94,7 \%$. Більше 80,0\% відсотків штамів демонстрували гарний ріст при додаванні у середовище фруктози, глюкози, маннози та манітолу. Мінімальна кількість штамів (31,6\% та 21,6\%, відповідно) росли у присутності арабінози та ксилози.

За ступенем утилізації актиноміцетами, ізольованими з обростань бетону, використані вуглецеві субстрати можна розташувати у наступному порядку: рамноза > глюкоза/фруктоза/манноза/манітол > цукроза/сорбітол/галактоза > гліцерол > арабіноза > ксилоза.

Іншими дослідниками також показано, що найменш придатним середовищем для росту актинобактерій є середовище 3 ксилозою [6].

Щодо актинобактерій, виділених із мідій, то штами Myt 1 i Myt 10 не здатні метаболізувати фруктозу і арабінозу та мають дуже помірний ріст на середовищах 3 ксилозою і сорбітолом.

\section{Джерело вуглецю}

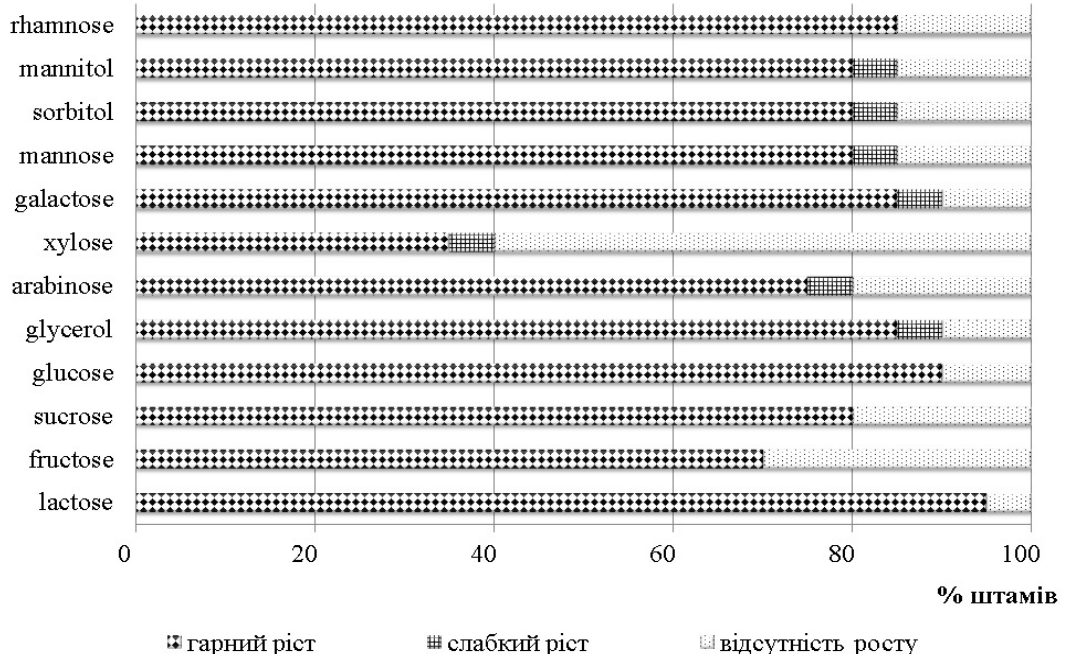

Рис. 3.12. Частка штамів актинобактерій, ізольованих із обростань черепашнику, здатних до ферментації джерел вуглецю 


\section{Джерело вуглецю}

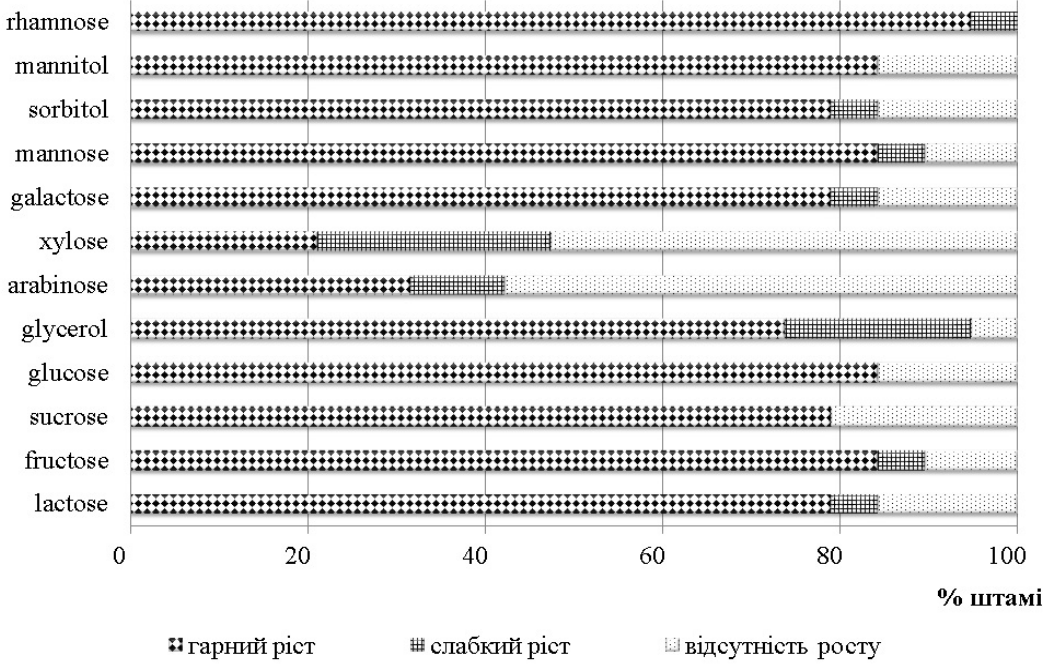

\section{Рис. 3.13. Частка штамів актинобактерій, ізольованих із обростань бетону, здатних до ферментації джерел вуглецю}

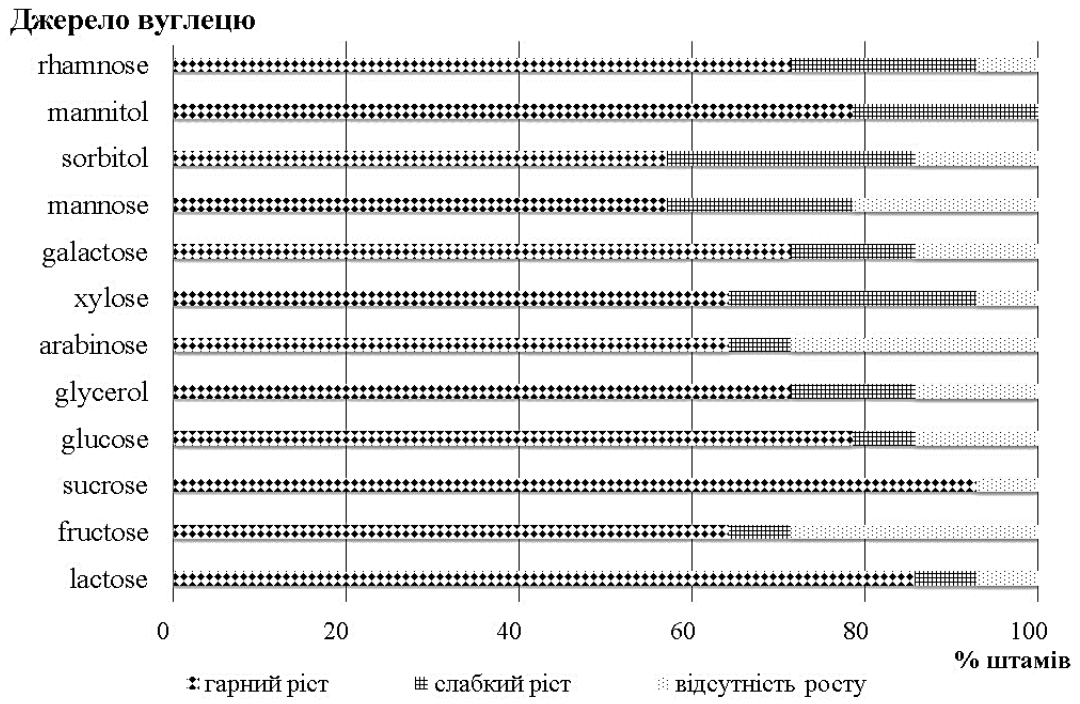

Рис. 3.14. Частка штамів актинобактерій, ізольованих із мідій, здатних до ферментації джерел вуглецю 
Найменшою здатністю залучати у свій метаболізм різні вуглецеві субстрати характеризувалися штами Myt 12a та Myt 12b. Для культивування цих штамів придатними є багатші органічні середовища, наприклад, Гаузе 2. Натомість, штам Myt 11 демонстрував гарний ріст на усіх вуглецевих субстратах [4].

Таким чином, штамам актиноміцетів, виділеним із різних джерел Чорного моря, притаманна досить висока метаболічна активність, що може бути запорукою активації різних метаболічних шляхів і є одним із можливих механізмів адаптації до мінливих умов довкілля.

\section{4. Ідентифікація та спектри жирних кислот актинобактерій}

Відомо, що ідентифікація актиноміцетів не до кінця відпрацьована. Це пояснюється з одного боку ототожненням видів із так званими "типовими” штамами стрептоміцетів, з іншого - описом нових видів без урахування внутрішньовидової мінливості. Встановлено, що, завдяки мінливості, у межах виду зустрічаються численні різновиди, які є, по суті, варіантами, природними або штучними мутантами 3 властивостями відмінними від материнського штаму [2].

Одним із підходів до попередньої ідентифікації актиноміцетів, принаймні до роду, є порівняння їх жирнокислотних спектрів [44], оскільки аналіз жирнокислотного складу загальних клітинних ліпідів є однією із важливих хемотаксономічних характеристик, яка корелює з результатами ідентифікації за молекулярно-генетичними показниками [74,79].

У цих дослідженнях проаналізовані результати визначення жирнокислотного складу, отримані для 31 штаму актиноміцетів, ізольованих із біологічних обростань бетонних поверхонь, природного черепашнику, пластику, металу та води Одеської затоки Чорного моря [3]. Завдяки автоматизованій системі ідентифікаціï мікроорганізмів MIDI Sherlock (MIDI Library ACTIN 3.80) [59] встановлено, що досліджені штами актиноміцетів з різними індексами подібності відносяться до двох родів Streptomyces i Nocardiopsis. Результати ідентифікації наведено у таблиці 3.4. 
Таблиця 3.4

\section{Ідентифікація актинобактерій, виділених із різних джерел Чорного моря, за спектрами жирних кислот допомогою бібліотеки MIDI Sherlock}

\begin{tabular}{|l|l|c|c|}
\hline \multicolumn{1}{|c|}{ Штам } & Рід & Джерело виділення & $\begin{array}{c}\text { Індекс } \\
\text { спорідненості }\end{array}$ \\
\hline Lim 2.2 & Streptomyces & черепашник & 0.063 \\
\hline Lim 3.1 & Streptomyces & черепашник & 0.053 \\
\hline Lim 3.2 & Streptomyces & черепашник & 0.065 \\
\hline Lim 5.2 & Streptomyces & черепашник & 0.166 \\
\hline Lim 6.1 & Streptomyces & черепашник & 0.404 \\
\hline Lim 6.2 & Streptomyces & черепашник & 0.225 \\
\hline Lim 7.1 & Nocardiopsis & черепашник & 0.001 \\
\hline Lim 7.2 & Streptomyces & черепашник & 0.061 \\
\hline Lim 9.1 & Streptomyces & черепашник & 0.609 \\
\hline Lim 9.2 & Streptomyces & черепашник & 0.268 \\
\hline Lim 10 & Streptomyces & черепашник & 0.302 \\
\hline Lim 12.1 & Streptomyces & черепашник & 0.110 \\
\hline Lim 12.2 & Streptomyces & черепашник & 0.072 \\
\hline Lim 12.3 & Streptomyces & черепашник & 0.132 \\
\hline Conc 1 & Nocardiopsis & бетон & 0.015 \\
\hline Conc 3 & Streptomyces & бетон & 0.002 \\
\hline Conc 5 1 & Streptomyces & бетон & 0.040 \\
\hline Conc 6b & Streptomyces & бетон & 0.091 \\
\hline Conc 6s & Streptomyces & бетон & 0.109 \\
\hline Conc 9 & Streptomyces & бетон & 0.517 \\
\hline Conc 11 & Streptomyces & бетон & 0.002 \\
\hline Conc 13 & Streptomyces & бетон & 0.014 \\
\hline Conc 15 & Streptomyces & бетон & 0.272 \\
\hline Conc 16a & Streptomyces & бетон & 0.077 \\
\hline Conc 21 & Streptomyces & бетон & 0.006 \\
\hline Conc 24 & Streptomyces & бетон & 0.265 \\
\hline Conc 29 & Nocardiopsis & бетон & 0.035 \\
\hline Conc 32 & Streptomyces & бетон & 0.005 \\
\hline Met 2 & Nocardiopsis & метал & 0.152 \\
\hline Plast 1 & Streptomyces & пластик & 0.250 \\
\hline Sea 2 & Streptomyces & морська вода & 0.066 \\
\hline
\end{tabular}


Переважна більшість штамів (87,1\% від усіх досліджених) за результатами ідентифікації віднесена до роду Streptomyces i лише 4 штами (12,9\%) - до роду Nocardiopsis. Як представники роду Nocardiopsis ідентифіковано 2 штами із обростань бетону (Conc 1 i Conc 29) та по одному штаму, виділених із черепашнику (Lim 7.1) і металу (Met 2). Отримані результати доповнюють численні наукові публікації щодо космолітичного розповсюдження представників роду Streptomyces. Зокрема, стрептоміцети досить часто і в переважній більшості виділяються із різних джерел морських (океанських) середовищ різних частин світу [23, 61, 64]. Так, наприклад, у публікації Tenebro et al. [70] повідомляється про ізоляцію із морських відкладень західно-центральної частини Філіппін 2212 штамів, які були ідентифіковані як стрептоміцети [70]. Із морських губок Південно-Китайського моря Wei Sun et al. [69] виділено 77 ізолятів, представників різних родів актиноміцетів; одними із домінуючих були представники роду Streptomyces, більше того, саме штам стрептоміцетів (Streptomyces anulatus S71) синтезував сполуку ароматичних полікетидів - ангуциклін [69]. Про виділення представників родів Streptomyces i Nocardiopsis, 3 цитоксичною і антагоністичною активністю із різних відкладень i проб морської води, зібраних поблизу узбережжя Червоного моря в Сгипті мова йде у праці Abdelfattah et al. [8].

Відомо, що актиноміцети за жирнокислотним складом поділяють на два типи. Види, у клітинах яких переважають жирні кислоти 3 розгалуженим ланцюгом, відносять до першого типу, а види, у клітинах яких значний відсоток насичених або мононенасичених жирних кислот з прямим ланцюгом,- до другого типу [52].

За даними літературних джерел профілі клітинних жирних кислот представників роду Streptomyces складаються переважно 3 12-17 насичених жирних кислот з розгалуженим ланцюгом з ISOта ANTEISO- положенням метильної групи. Метилові розгалужені жирні кислоти є маркерами актиноміцетів [20, 44, 71]. Проведений хроматографічний аналіз жирнокислотних спектрів виділених актиноміцетів роду Streptomyces показав наявність у їх складі ізомерів розгалужених насичених і ненасичених жирних кислот із загальною кількістю атомів вуглецю від 10 до 17 (табл. 3.5). 
Жирнокислотний склад (\%) клітин актинобактерій роду Streptomyces

\begin{tabular}{|c|c|c|c|c|c|c|c|c|c|}
\hline $\begin{array}{c}\text { Жирна } \\
\text { кислота }\end{array}$ & \multirow{2}{*}{$\begin{array}{l}\varrho \\
\stackrel{\varrho}{0} \\
\stackrel{\theta}{\theta}\end{array}$} & \multirow{2}{*}{ 荨兽 } & \multirow{2}{*}{ 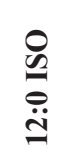 } & \multirow{2}{*}{ 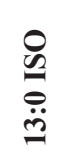 } & \multirow{2}{*}{ 邑怘 } & \multirow{2}{*}{ 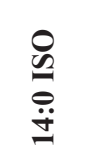 } & \multirow{2}{*}{ 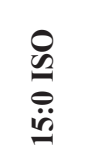 } & \multirow{2}{*}{ 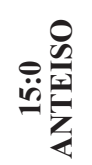 } & \multirow{2}{*}{$\underset{\ddot{\theta}}{\ddot{\theta}}$} \\
\hline Штам & & & & & & & & & \\
\hline 1 & 2 & 3 & 4 & 5 & 6 & 7 & 8 & 9 & 10 \\
\hline $\operatorname{Lim} 2.2$ & $*_{-}$ & 0,28 & 0,63 & 0,66 & 1,16 & 10,84 & 8,97 & 38,74 & 2,07 \\
\hline $\operatorname{Lim} 3.1$ & 0,5 & - & - & 0,11 & 0,35 & 2,82 & 5,8 & 55,09 & 1,91 \\
\hline $\operatorname{Lim} 3.2$ & - & - & 1,73 & 0,39 & 0,66 & 7,13 & 5,9 & 32,14 & 0,84 \\
\hline $\operatorname{Lim} 5.2$ & - & - & 0,47 & 0,7 & 0,7 & 7,6 & 13,71 & 31,77 & 2,09 \\
\hline $\operatorname{Lim} 6.1$ & 0,09 & 0,11 & 0,39 & 0,33 & 0,76 & 3,6 & 7,67 & 34,07 & 2,11 \\
\hline $\operatorname{Lim} 6.2$ & 0,05 & 0,26 & 0,48 & 0,49 & 1,4 & 4,78 & 7,55 & 33,87 & 1,86 \\
\hline $\operatorname{Lim} 7.2$ & - & - & - & - & 0,13 & 2,91 & 6,46 & 48,54 & 1,64 \\
\hline $\operatorname{Lim} 9.1$ & - & 0,07 & 0,17 & 0,22 & 0,47 & 6,05 & 10,26 & 34,33 & 1,84 \\
\hline $\operatorname{Lim} 9.2$ & 0,14 & 0,3 & 0,62 & 0,3 & 0,79 & 8,12 & 9,96 & 28,54 & 2,33 \\
\hline $\operatorname{Lim} 10$ & - & - & 0,56 & 0,46 & 0,68 & 9,14 & 10,67 & 26,0 & 1,96 \\
\hline Lim 12.1 & - & - & - & - & - & 5,43 & 7,75 & 43,8 & 1,43 \\
\hline Lim 12.2 & - & - & 0,11 & 0,1 & 0,33 & 3,08 & 6,58 & 35,01 & 1,07 \\
\hline $\operatorname{Lim} 12.3$ & - & - & - & 0,06 & 0,16 & 3,1 & 5,35 & 42,62 & 1,32 \\
\hline Conc 3 & - & - & - & - & 0,24 & 6,65 & 5,63 & 48,34 & 1,08 \\
\hline Conc 5_1 & - & - & - & 0,57 & 0,6 & 2,54 & 17,46 & 41,64 & 0,57 \\
\hline Conc $6 \mathrm{~b}$ & 0,08 & 0,1 & 0,14 & 0,33 & 0,46 & 4,86 & 7,52 & 33,16 & 1,86 \\
\hline Conc 6s & - & 0,08 & - & 0,25 & 0,39 & 2,43 & 7,17 & 35,06 & 1,75 \\
\hline Conc 9 & - & - & - & 0,29 & 0,39 & 0,39 & 15,11 & 34,28 & 0,76 \\
\hline Conc 11 & 0,97 & - & - & 0,34 & 0,38 & 7,31 & 6,32 & 27,12 & 2,2 \\
\hline Conc 13 & 0,24 & - & - & 0,16 & 0,27 & 4,87 & 7,58 & 24,23 & 1,5 \\
\hline Conc 15 & - & - & - & 0,48 & 0,43 & 5,44 & 12,22 & 33,67 & 2,47 \\
\hline Conc 16a & 0,11 & 0,59 & 0,18 & 0,44 & 1,53 & 2,05 & 8,58 & 48,89 & 1,67 \\
\hline Conc 21 & 0,74 & - & - & 0,14 & 0,32 & 8,59 & 4,37 & 30,3 & 1,71 \\
\hline Conc 24 & 0,15 & - & 0,35 & 0,24 & 0,38 & 15,69 & 6,03 & 29,7 & 1,77 \\
\hline Conc 32 & 1,94 & - & - & 0,16 & 0,34 & 10,66 & 4,61 & 25,82 & 1,59 \\
\hline Plast 1 & - & 0,2 & 0,62 & 0,7 & 1,16 & 10,92 & 7,93 & 39,5 & 2,07 \\
\hline Sea 2 & 1,28 & - & - & 0,06 & 0,14 & 2,88 & 3,39 & 48,58 & 0,91 \\
\hline
\end{tabular}

Примітка: *- не виявлено. 


\begin{tabular}{|c|c|c|c|c|c|c|c|c|c|}
\hline 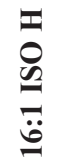 & 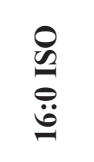 & $\begin{array}{l}a \\
\tilde{U} \\
\ddot{\ddot{\theta}}\end{array}$ & $\stackrel{\ddot{\theta}}{\ddot{\theta}}$ & 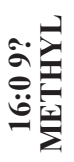 & 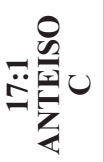 & 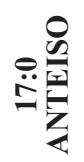 & 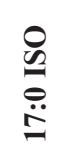 & $\begin{array}{l}a \\
\tilde{U} \\
\ddot{0}\end{array}$ & نِ \\
\hline 11 & 12 & 13 & 14 & 15 & 16 & 17 & 18 & 19 & 20 \\
\hline 3,14 & 14,03 & 4,0 & 5,22 & - & 1,65 & 5,53 & 1,16 & 0,35 & - \\
\hline 0,92 & 8,7 & 1,99 & 3,77 & 1,06 & 2,72 & 9,78 & 1,17 & 0,49 & 1,23 \\
\hline 1,77 & 10,84 & 1,07 & 2,23 & - & 3,38 & 5,61 & 1,11 & 0,19 & 2,62 \\
\hline 3,06 & 16,14 & 4,86 & 5,26 & 2,17 & 1,88 & 5,16 & 2,09 & 0,51 & 0,49 \\
\hline 2,83 & 12,08 & 5,37 & 6,49 & 3,01 & 5,54 & 10,61 & - & 2,34 & 0,17 \\
\hline 4,0 & 12,78 & 5,13 & 4,87 & 2,65 & 5,05 & 9,04 & 1,72 & 0,83 & - \\
\hline 1,14 & 9,91 & 0,96 & 3,01 & 2,02 & 4,14 & 9,31 & 1,43 & 0,43 & 3,35 \\
\hline 3,19 & 19,31 & 3,06 & 4,59 & 1,92 & 1,88 & 8,38 & 2,2 & 0,4 & 0,71 \\
\hline 7,28 & 19,87 & 3,71 & 2,76 & 2,32 & 2,62 & 5,2 & 1,47 & 0,54 & 0,97 \\
\hline 6,89 & 23,43 & 2,82 & 3,65 & 1,83 & 2,06 & 5,16 & 1,92 & - & 1,7 \\
\hline 1,69 & 15,18 & 1,65 & 3,19 & 2,1 & 3,83 & 6,55 & 1,38 & 0,52 & 3,15 \\
\hline 1,13 & 19,71 & 1,12 & 4,02 & 2,08 & 3,45 & 13,59 & 2,86 & 0,42 & 2,3 \\
\hline 1,39 & 14,68 & 3,48 & 5,5 & 1,18 & 2,57 & 11,06 & 1,47 & 0,54 & 1,19 \\
\hline 0,9 & 11,69 & 0,61 & 2,81 & 1,22 & 3,17 & 6,22 & 0,99 & - & 1,59 \\
\hline 2,52 & 10,91 & 1,73 & 2,46 & 0,58 & 0,96 & 12,46 & 4,43 & - & - \\
\hline 4,14 & 13,8 & 10,17 & 6,6 & 1,81 & 3,19 & 7,25 & 1,54 & 0,74 & 0,26 \\
\hline 1,87 & 9,31 & 10,42 & 9,53 & 1,72 & 3,81 & 10,22 & 2,03 & 0,55 & 0,26 \\
\hline 1,31 & 9,83 & 2,38 & 3,79 & 2,25 & 3,51 & 17,4 & 6,39 & - & - \\
\hline 4,21 & 14,25 & 7,74 & 5,08 & 1,11 & 2,13 & 4,72 & 0,84 & 0,59 & - \\
\hline 6,28 & 13,47 & 7,63 & 3,67 & 2,39 & 4,3 & 6,79 & 1,11 & 0,44 & - \\
\hline 2,24 & 11,86 & 6,4 & 9,26 & 2,02 & 1,7 & 6,12 & 2,26 & 0,53 & 0,85 \\
\hline 0,96 & 4,77 & 5,54 & 6,25 & 1,99 & 3,56 & 8,71 & 2,11 & 0,61 & 0,2 \\
\hline 6,03 & 14,43 & 4,7 & 4,05 & 1,32 & 3,81 & 6,45 & 0,64 & 0,48 & 2,04 \\
\hline 2,76 & 19,76 & 4,03 & 7,04 & 0,96 & 1,74 & 4,87 & 1,53 & 0,43 & 1,11 \\
\hline 5,17 & 16,28 & 4,24 & 4,01 & 1,07 & 2,84 & 5,95 & 0,78 & 0,39 & 1,15 \\
\hline 3,14 & 15,07 & 4,0 & 5,22 & - & 1,65 & 5,61 & 1,18 & 0,43 & - \\
\hline 0,71 & 10,87 & 1,69 & 3,83 & 1,35 & 3,62 & 12,73 & 1,23 & 0,52 & 2,96 \\
\hline
\end{tabular}


Встановлено, що у спектрах стрептоміцетів провідну роль відігравали12-метилтетрадеканова кислота (ії кількість у відсотковому відношенні коливалася від 22,82\% до 55,09\%), 14-метилпентадеканова кислота $(4,77 \%-23,43 \%)$, 12-метилтридеканова кислота (0,39\%-15,69\%), 14-метилгексадеканова кислота (4,72\%$17,4 \%)$ та 13-метилтетрадеканова кислота (3,39\%-17,46\%). Майже усі штами містили невеликий відсоток C17:0 CYCLO (цис-9,10-метиленгексадеканової кислоти), що є корисним маркером для ідентифікації бактерій роду Streptomyces [52].

Статистичний аналіз жирнокислотних профілів досліджених штамів актиноміцетів роду Streptomyces, проведений за допомогою програмного забезпечення MIDI Library Generation System дав змогу збудувати дендрограму на основі евклідової відстані (рис. 3.15).

Статистичні відмінності у кількісних показниках 9-цис-гексадеценової кислоти у жирнокислотному профілі стрептоміцетів $\epsilon$ підгрунтям для виокремлення двох груп. Для першої групи характерним є відсоткове відношення 16:1 CIS 9 (пальмітолеїнової кислоти) від 0,61\% до 2,82\%, для другої - від 3,06\% до 10,42\%.

Кількісні відмінності у відсотковому відношенні 13-метилтетрадеканової кислоти обумовлюють поділ штамів першої групи на дві підгрупи (А і Б) на евклідовій відстані 15 [3].

Для підгрупи А характерним є наявність C15:0 ISO (13-метилтетрадеканової кислоти) у відсоткових межах від 10,61\% до 17,46\%, для підгрупи Б - від 3,39\% до 7,75\%.

Для другої групи також має місце поділ на дві підгрупи (B i Г) на евклідовій відстані 17,5, але за іншими ознаками. У штамів підгрупи В відсоткове відношення 14-метилгексадеканової кислоти становить від 0,96\% до 4\%, а 15-метилпентадеканової кислоти - від 1,16\% до 2,26\%. Для підгрупи Г відсоткове відношення для C16:1 ISO складає від 4,21\%-6,28\%, а для C17:0 ISO - від $0,64 \%$ до $1 \%$.

Щодо виділених актиноміцетів, ідентифікованих як представники роду Nocardiopsis, аналіз хроматограм показав, що склад жирних кислот клітин містить ізомери насичених та ненасичених жирних кислот із загальною кількістю атомів вуглецю від 13 до 19 (табл. 3.6). У жирнокислотних профілях досліджених 


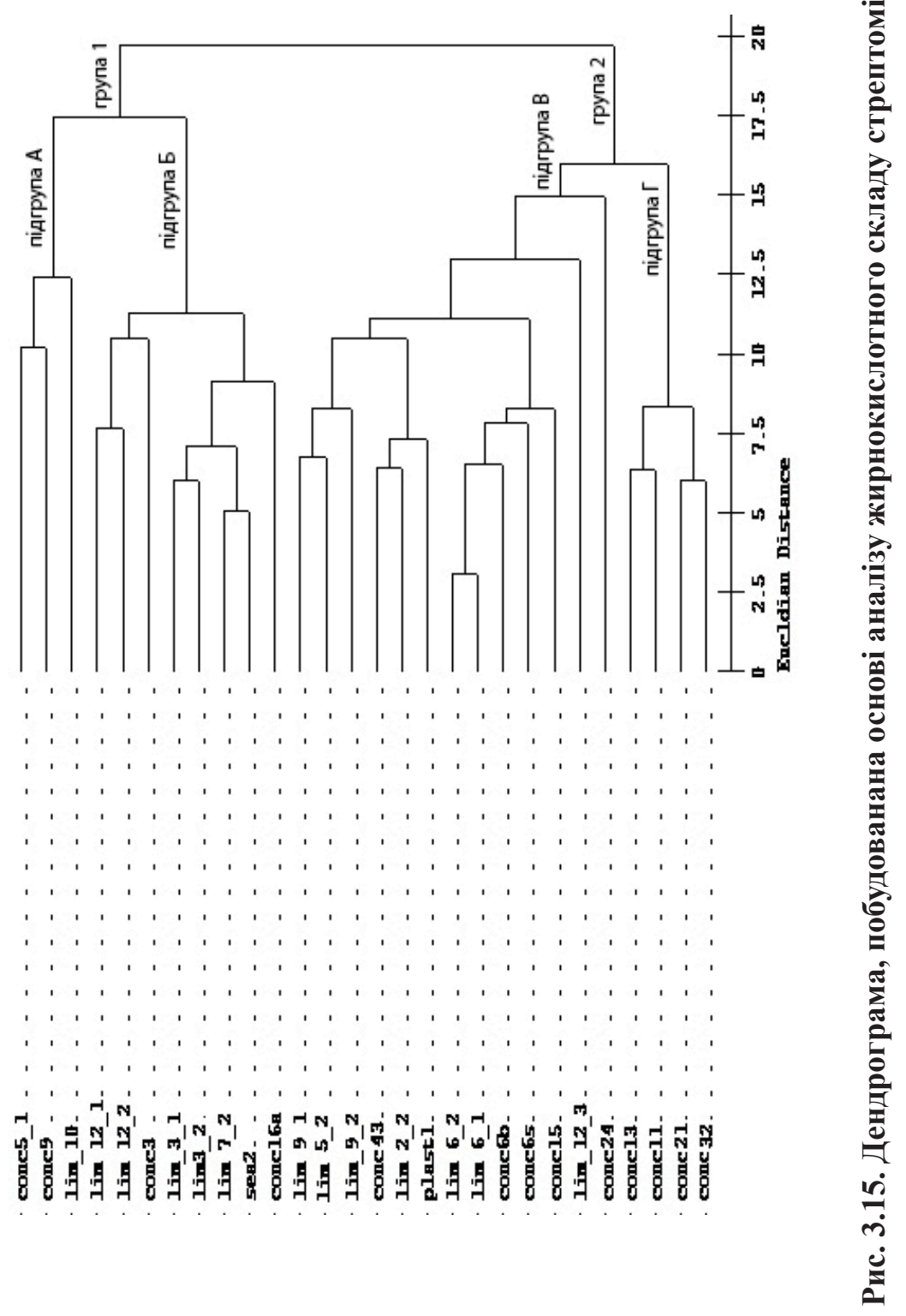


Таблиця 3.6

Жирнокислотний склад (\%) клітин актинобактерій роду Nocardiopsis

\begin{tabular}{|l|c|c|c|c|}
\hline \multirow{2}{*}{ Жирна кислота } & \multicolumn{4}{|c|}{ Штам } \\
\cline { 2 - 5 } & Lim 7.1 & Conc 1 & Conc 29 & Met 2 \\
\hline 13:0 ISO & 0,13 & 0,13 & 0,24 & $*$ - \\
\hline 13:0 ANTEISO & 0,63 & 0,86 & 0,74 & 1,67 \\
\hline 14:0 ISO & 1,3 & 1,0 & 1,18 & 12,01 \\
\hline 14:0 & 0,5 & 0,22 & 0,23 & 0,79 \\
\hline 15:0 ISO & 1,64 & 1,47 & 1,05 & 1,48 \\
\hline 15:0 ANTEISO & 9,14 & 10,36 & 7,08 & 6,83 \\
\hline 15:0 & - & 0,31 & 24,93 & - \\
\hline 16:0 ISO & 15,61 & 19,2 & 1,79 & 36,71 \\
\hline 16:1 CIS 9 & 1,45 & 2,71 & 2,38 & - \\
\hline 16:0 & 2,26 & 3,46 & 2,38 & 1,69 \\
\hline 17:1 ANTEISO C & 1,22 & - & 3,78 & - \\
\hline 17:0 ISO & 3,1 & 2,31 & 1,73 & 1,8 \\
\hline 17:0 ANTEISO & 22,59 & 29,42 & 22,59 & 9,5 \\
\hline 17:1 CIS 9 & 4,59 & 3,25 & 6,18 & - \\
\hline 17:0 & 1,67 & 1,55 & 2,26 & 1,93 \\
\hline 17:0 10METHYL & 0,98 & 0,66 & 1,03 & - \\
\hline 18:0 ISO & 1,82 & 1,36 & 1,55 & 1,89 \\
\hline 18:1 CIS 9 & 16,39 & 14,45 & 12,17 & - \\
\hline 18:0 & 3,86 & 4,61 & 4,3 & 1,35 \\
\hline 19:0 ANTEISO & - & 0,41 & 0,4 & - \\
\hline 19:0 & 0,23 & - & - & - \\
\hline
\end{tabular}

Примітка: *- не виявлено. 
штамів актиноміцетів роду Nocardiopsis переважали такі жирні кислоти: 12-метилтетрадеканова кислота (від 6,83\% до 10,36\%), 14 -метилпентадеканова кислота (1,79\%-36,71\%), 14-метилгексадеканова кислота (9,5\%-29,42\%), (9Z)-октадеценова кислота (від $12,17 \%$ до $16,39 \%$ ) [3].

Привертає увагу особливість спектру жирних кислот штамy Nocardiopsis sp. Conc 29, у профілі якого переважала пентадеканова кислота (C15:0). Загальна кількість цієї кислоти сягала $24,93 \%$, тоді як у інших штамів цього роду вона склала $0,31 \%$, або не виявлялася зовсім (табл. 3.6).

Проведений хроматографічний аналіз показав, що для всіх виділених актиноміцетів роду Nocardiopsis притаманною є наявність вищих жирних кислот із загальною кількістю атомів вуглецю 18-19 (16-метилгептадеканова, (9Z)-октадеценова, октадеканова, 16-метилоктадеканова та нонадеканова кислоти) [3].

Свого часу в опублікованих результатах досліджень Kroppenstedt [44] i Hozzein et al. [33] показано, що бактерії роду Nocardiopsis характеризуються розгалуженими ізомерами насичених жирних кислот, серед яких основними є 14-метилгептадеканова кислота (C16:0 ISO) і 14-метилгексадеканова кислота (C17:0 ANTEISO) $[33,44]$. Також цими авторами показано наявність у жирнокислотних профілях Nocardiopsis, правда дещо у меншій кількості, 10-метил розгалуженої туберкулостеаринової кислоти, тобто 10-метилоктадеканової кислоти (C18:010 METHYL), та iii попередника ненасиченої цис-9,10-октадеценової кислоти (C18:1 CIS). Отримані результати визначення складу клітинних ліпідів штамів актиноміцетів роду Nocardiopsis, виділених із Чорного моря, не відрізняються від вище наведених показників зазначених авторів.

Зауважимо, що жирнокислотні профілі актиноміцетів обох родів характеризуються наявністю ізомерів розгалужених насичених жирних кислот, що свідчить про їх належність до першого типу актиноміцетів [52].

Отже, в результаті проведених мікробіологічних досліджень вперше актиноміцети ізольовано із біологічних обростань черепашнику, бетону та інших поверхонь, а також із мушлі мідій Одеської затоки Чорного моря; досліджено їх морфологічні, куль- 
туральні, фізіолого-біохімічні і хемотаксономічні властивості. За результатами попередньої ідентифікації встановлено, що незважаючи на досить високу морфологічну варіабельність, здатність утворювати різні морфотипи колоній при рості на поживних середовищах, всі штами актиноміцетів представлені двома родами: Streptomyces i Nocardiopsis iз суттєвим домінуванням представників роду Streptomyces.

\section{СПИСОК ВИКОРИСТАНОЇ ЛІТЕРАТУРИ}

1. Білявська Л. О. Актинобактерії роду Streptomyces i їхні метаболіти у біорегуляції рослин: дис. ... док. біол. наук: 03.00.07. - Київ, 2018. - 485 с.

2. Валагурова Е. В., Козырицкая В. Е., Иутинская Г. А. Актиномицеты рода Streptomyces, описание видов и компьютерная программа их идентификации. - Киев: Наукова думка, 2003. - 618 c.

3. Коротаєва Н. В., Потапенко К. С., Страшнова I. В., Метеліцина І. П., Іваниця В. О. Спектри жирних кислот актинобактерій з біологічних обростань Одеської затоки Чорного моря // Мікробіологія і біотехнологія. - 2021. - № 3. С 6070. http://dx.doi.org/10.18524/2307-4663.2021.3(53).245369

4. Коротаєва Н. В., Страшнова І. В., Васильєва Н. Ю., Потапенко К. С., Метеліцина І. П., Філіпова Т. О., Іваниця В. О. Характеристика актинобактерій, ізольованих із Mytilus galloprovincialis Одеської затоки Чорного моря // Мікробіологія і біотехнологія. - 2021. - № 3. - C. 84-98. http://dx.doi. org/10.18524/2307-4663.2021.3(53).246392

5. Потапенко К. С., Коротаєва Н. В., Іваниця В. О. Вторинні метаболіти морських актинобактерій з антибіотичною активністю // Мікробіологія і біотехнологія. - 2021 . - № 3. - С. 2843. http://dx.doi.org/10.18524/2307-4663.2021.3(53).245323

6. Сищикова О. В. Біологічні властивості та таксономічний склад стрептоміцетів природних грунтів техноземів Криворіжжя // Мікробіологія і біотехнологія. - 2014. - № 1. C. 91-104.

7. Страшнова I. В., Коротаєва Н. В., Потапенко К. С., Васильєва Н. Ю., Чабан М. М., Штеніков М. Д., Лісютін Г. В., 
Іваниця В. О. Актинобактерії обростання твердих субстратів Одеської затоки Чорного моря // Морський екологічний журнал. - 2021. - № 2. - у друці.

8. Abdelfattah M. S., Elmallah M. I. Y., Hawas U. W., El-Kassema L. T. A., Eid M. A. G. Isolation and characterization of marine-derived actinomycetes with cytotoxic activity from the Red Sea coast // Asian Pacific Journal of Tropical Biomedicine. - 2016. - V. 6, № 8. - P. 651-657. https://doi.org/10.1016/j. apjtb.2016.06.004

9. Amin D. H., Abdallah N. A., Abolmaaty A., Tolba S., Wellington E. M. H. Microbiological and molecular insights on rare Actinobacteria harboring bioactive prospective // Bulletin of the National Research Centre. - 2020. - P. 1-12. https://doi. org/10.1186/s42269-019-0266-8

10. Analysis User's Manual.- Ver 6.0.- Newark, Del. -2005.-50 p.

11. Anderson A. S., Wellington E. M. H. The taxonomy of Streptomyces and related genera // Journal Systematic and Evolution Microbiology. - 2001. - V. 51, № 3. - P. 797-814. https://doi. org/10.1099/00207713-51-3-797

12. Antony-Babu S., Stach J. E., Goodfellow M. Genetic and phenotypic evidence for Streptomyces griseus ecovars isolated from a beach and dune sand system // Antonie Van Leeuwenhoek. 2008. - V. 94, № 1. - P. 63-74.

13. Arai T., Mikami Y. Choromogenecity of Streptomyces // Appl. Microbiol. - 1972. - V. 23. - P. 402-406.

14. Arul J. P., Jha B. Intertidal marine sediment harbours Actinobacteria with promising bioactive and biosynthetic potential // Scientific Reports. - 2017. - V. 7. - P. 1-15. doi:10.1038/ s41598-017-09672

15. Baral B., Akhgari A., Metsä-Ketelä M. Activation of microbial secondary metabolic pathways: Avenues and challenges // Synthetic and Systems Biotechnology. - 2018. - V. 3, № 3. P. 163-178. doi: 10.1016/j.synbio.2018.09.001

16. Barka E. A., Vatsa P., Sanchez L., Gaveau-Vaillant N., Jacquard C., Klenk H.-P. et al. Taxonomy, physiology and natural products of Actinobacteria // Microbiol. Mol. Biol. Rev. - 2016. - V. 80. - P. 1-43. 
17. Berdy J. Thoughts and facts about antibiotics: Where we are now and where we are heading // J. Antibiot. - 2012. - V. 65. P. 385-395.

18. Bhatti A. A., Haq S., Bhat R. A. Actinomycetes benefaction role in soil and plant health // Microb. Pathogenesis. - 2017. - V. 111. - P. 458-467. https://doi.org/10.1016/j.micpath.2017.09.036

19. Bhuneshwari S., Roymon M. G. Review on current techniques in isolation and characterization of Streptomyces from soil // Ind. J. Sci. Res. - 2017. - V. 13, № 2. - P. 226-232.

20. Bossio D. A., Fleck J. A., Scow K. M., Fujii R. Alteration of soil microbial communities and water quality inrestored wetlands // Soil Biol Biochem. - 2006. - V. 38. - P. 1223-1233.

21. Bredholdt H., Galatenko O. A., Engelhardt K., Fjærvik E., Terekhova L. P., Zotchev S. B. Rare actinomycete bacteria from the shallow water sediments of the Trondheim fjord, Norway: isolation, diversity and biological activity // Environmental Microbiology. - 2007. - V. 9, № 11. - P. 2756-2764. doi:10.1111/ j.1462-2920.2007.01387.x

22. Butler M. J., Day A. W. Fungal melanins: a review // Can. J. Microbiol. - 1998. - V. 44. - P. 1115-1136.

23. Cumsille A., Undabarrena A., Gonzalez V., Claveras F., Rojas C., Camara B. Biodiversity of actinobacteria from the South Pacific and the assessment of Streptomyces chemical diversity with metabolic profiling // Marine Drugs. - 2017. - V. 15. P. 1-21. doi:10.3390/md15090286

24. Dastager S. G., Li W. J., Dayanand A., Tang S-K., Tian X-P., Zhi X-Y. et al. Separation, identification and analysis of pigment (melanin) production in Streptomyces // African Journal of Biotechnology. - 2006. - V. 5, № 8. - P. 1131-1134.

25. Davies-Bolorunduro O. F., Adeleye I. A., Akinleye M. O., Wang P. G. Anticancer potential of metabolic compounds from marine actinomycetes isolated from Lagos Lagoon sediment // Journal of Pharmaceutical Analysis. - 2019. - V. 9, № 3. P. 201-208. doi: 10.1016/j.jpha.2019.03.004

26. Dhakal D., Pokhrel A. R., Shrestha B., Sohng J. K. Marine Rare Actinobacteria: Isolation, Characterization, and Strategies for Harnessing Bioactive Compounds // Frontiers in Mi- 
crobiology. - 2017. - V. 8, № 1106. - P. 1-13. doi: 10.3389/ fmicb.2017.01106

27. Ding T., Yang L-G., Zhang W-D., Shen Y-H. The secondary metabolites of rare actinomycetes: chemistry and bioactivity // RSC Advances. - 2019. - V. 9, № 38. - P. 21964-21988. https:// doi.org/10.1039/C9RA03579F

28. Ettoumia B., Chouchanec H., Guesmia A., Mahjoubi M., Brusetti L., Neifar M. et al. Diversity, ecological distribution and biotechnological potential of Actinobacteria inhabiting seamounts and non-seamounts in the Tyrrhenian Sea // Microbiological Research. - 2016. - V. 186-187. - P. 71-80. doi: 10.1016/j.micres.2016.03.006

29. Fenical W., Jensen P. R. Developing a new resource for drug discovery: marine actinomycete bacteria // Nat. Chem. Biol. 2006. - V. 2. - P. 666-673.

30. Gozari M., Bahador N., Jassbi A. R., Mortazavi M. S., Hamzehei S., Eftekha E. Isolation, distribution and evaluation of cytotoxic and antioxidant activity of cultivable actinobacteria from the Oman Sea sediments // Acta Oceanol. Sin. - 2019. - V. 38, № 12. - P. 84-90. https://doi.org/10.1007/s13131-019-1515-2

31. Gromyko O., Tistechok S., Roman I., Aravitska O., Luzhetskyy A., Parnikoza I., Fedorenko V. Isolation and characterization of culturable actinobacteria associated with Polytrichum strictum (Galindez Island, the maritime Antarctic) // Ukrainian Antarctic Journal.-2021.-V. 1.-P. 82-97.https://doi.org/10.33275/17277485.1.2021.668

32. Han S. K., Nedashkovalskaya O. I., Mikhailov V. V., Kim S. B., Bae K. S. Salinibacterium amurskyense gen nov., sp. nov., a novel genus of the family Microbacteriaceae from marine environment // Int. J. Syst. Evol. Microbiol. - 2003. - V. 53. P. 2061-2066.

33. Hozzein W. N., Trujillo M. E. Nocardiopsis. In Bergey's Manual of Systematics of Archaea and Bacteria / Eds. M. E. Trujillo, S. Dedysh, P. DeVos, B. Hedlund, P. Kämpfer, F. A. Raineyand, W. B. Whitman - Springer, 2015. doi:10.1002/9781118960608. gbm00195 
34. Hozzein W. N., Mohany M., Alhawsawi S. M. M., Zaky M. Y., Al-Rejaie S. S., Alkhalifah D. H. M. Flavonoids from marine-derived actinobacteria as anticancer drugs // Curr. Pharm. Des. - 2021. - V. 27. - P. 505-512. doi: 10.2174/13816128266 66201216160154

35. Hui M. L.-Y., Tan L. T.-H., Letchumanan V., He Y.-W., Fang C.M., Chan K.-G. et al. The Extremophilic Actinobacteria: From Microbes to Medicine // Antibiotics. - 2021. - V. 10. - P. 1-15. https://doi.org/10.3390/antibiotics10060682

36. Iizuka T., Jojima Y., Fudou R., Yamanaka S. Isolation of myxobacteria from the marine environment // FEMS Microbiology Letters. - 1998. - V. 169, № 2. - P. 317-322. doi. org/10.1111/j.1574-6968.1998.tb13335.x

37. Imada C., Masuda S., Kobayashi T., Hamada-Sato N., Nakashima T. Isolation and Characterization of Marine and Terrestrial Actinomycetes Using a Medium Supplemented with $\mathrm{NaCl} / /$ Actinomycetologica. - 2010. - V. 24. - P. 12-17.

38. Jagannathan S. V., Manemann E. M., Rowe S. E., Callender M. C., Soto W. Marine Actinomycetes, new sources of biotechnological products // Marine Drugs. - 2021. - V. 19. P. 1-30. https://doi.org/10.3390/md19070365

39. Jayashanth E. Actinobacteria - morphology, physiology, biochemistry, diversity and Industrial Applications of genus Actinobacteria: Microbiology Assignment, 2015. - P. 1-16. doi:10.13140/RG.2.1.2632.5928

40. Jenifer J. S. C. A., Donio M. B. S., Michaelbabu M., Vincent S. G. P., Citarasu T. Haloalkaliphilic Streptomyces spp. AJ8 isolated from solar salt works and its' pharmacological potential // Springer Open Journal. - 2015. - V. 5. - P. 1-12. doi: 10.1186/ s13568-015-0143-2

41. Jiang Y., Li Q., Chen X., Jiang C. Isolation and cultivation methods of Actinobacteria // Actinobacteria-Basics and Biotechnological Applications / Eds. D. Dhanasekaran, Y. Jiang. - InTech: London, UK, 2016. - P. 39-57.

42. Kashfi R., Kelsey C., Gang D. J., Cal D. R., Gang D. R. Metabolomic diversity and identification of antibacterial activities of bacteria isolated from marine sediments in Hawai'i and Puerto 
Rico // Frontiers in Molecular Biosciences. - 2020. - V. 7. P. 1-15. https://doi.org/10.3389/fmolb.2020.00023

43. Khan S. N.,Khan A. U. Breaking thes pell: Combating multidrug resistant 'Superbugs' // Front. Microbiol. - 2016. - V. 7. - P. 174.

44. Kroppenstedt R. M. Fatty acid and menaquinone analysis of actinomycetes and related organisms // Chemical Methods in Bacterial Systematics / Eds. M. Goodfellow, D. E. Minnikin. London: Academic Press, 1985. - P. 173-199.

45. Lewin G. R., Carlos C., Chevrette M. G., Horn H. A., McDonald B. R., Stankey R. J. Evolution and Ecology of Actinobacteria and their bioenergy applications // Annu Rev Microbiol. - 2016. - V. 70, № 1. - P. 235-254. doi: 10.1146/annurev-micro-102215-095748

46. Lin W. P., Lai H. L., Liu Y. L., Chiung Y. M., Shiau C. Y., Han J. M. et al. Effect of melanin produced by a recombinant Escherichia coli on antibacterial activity of antibiotics // J. Microbiol. Immunol. Infect. - 2005. - V. 38. - P. 320-326.

47. Maldonado L. A., Fenical W., Jensen P. R., Kauffman C. A., Mincer T. J., Ward A. C. et al. Salinispora arenicola gen. nov., and Salinispora tropica sp. nov., obligate marine actinomycetes belonging to the family Micromonosporaceae // Int. J. Syst. Evol. Microbiol. - 2005. - V. 55. - P. 1759-1766.

48. Malve H. Exploring the ocean for new drug developments: Marine pharmacology // Journal of pharmacy bioallied sciences. 2016. - V. 8. - P. 83-91. doi: 10.4103/0975-7406.171700

49. Manivasagan P., Venkatesan J., Kim S.-K. Introduction to Marine Actinobacteria // Marine Microbiology: Bioactive Compounds and Biotechnological Applications / Ed. Se-Kwon Kim. - Wiley-VCH Verlag GmbH \& Co. KGaA, 2013. - P. 1-19. https://doi.org/10.1002/9783527665259.ch01

50. Manivasagan P., Venkatesan J., Sivakumar K., Kim S.-K. Marine actinobacterial metabolites: current status and future perspectives // Microbiological Research. - 2013. - V. 168, № 6. - P. 311-332. doi: 10.1016/j.micres.2013.02.002

51. Maria A. B. F., Sharmili A. S., Anbumalarmathi J. Isolation and characterization of actinomycetes from marine soil // MOJ Biol 
Med. - 2018. - V. 3, № 6. - P. 221-225. doi: 10.15406/mojbm.2018.03.00103

52. McNabb A., Shuttleworth R., Behme R., Colby W. D. Fatty acid characterization of rapidly growing pathogenic aerobic actinomycetes as a means of identification // Journal of Clinical Microbiology. - 1997. - V. 35, № 6. - P. 1361-1368.

53. MIS Operation Manual.www.midi-inc.com. September. -2012. - Newark.

54. Parte A. C., Sardà Carbasse J., Meier-Kolthoff J. P., Reimer L. C., Goker M. List of Prokaryotic names with Standing in Nomenclature (LPSN) moves to the DSMZ // International Journal of Systematic and Evolutionary Microbiology. - 2020. - V. 70. - P. 5607-5612. doi: 10.1099/ijsem.0.004332

55. Qinyuan Li, Xiu Chen, Yi Jiang, Chenglin Jiang. Cultural, Physiological, and Biochemical Identification of Actinobacteria // Actinobacteria - Basics and Biotechnological Applications / Eds. D. Dhanasekaran and Yi Jiang. - IntechOpen, 2016. http:// dx.doi.org/10.5772/61462

56. Ribeiro I., Girão M., Alexandrino D. A. M., Ribeiro T., Santos C., Pereira F. et al. Diversity and Bioactive Potential of Actinobacteria Isolated from a Coastal Marine Sediment in Northern Portugal // Microorganisms. - 2020. - V. 8, № 11. - P. 1-16. https://doi.org/10.3390/microorganisms8111691

57. Sabido E. M., Tenebro C. P., Suarez A. F. L., Ong S. D. C., Von L. Trono D. J., Amago D. S. et al. Marine sediment-derived Streptomyces strain produces angucycline antibiotics against multidrug-resistant Staphylococcus aureus harboring SCCmec type 1 gene // J Mar Sci Eng - 2020. - V. 8. - P. 1-19. https:// doi.org/10.3390/jmse8100734

58. Salvan R., Sharma V. Molecular and biotechnological aspects of secondary metabolites in actinobacteria // Microbiological Research. - 2020. - V. 231. - P. 1-18. https://doi.org/10.1016/j. micres.2019.126374

59. Sasser M. Bacterial identification by gas chromatographic analysis of fatty acid methyl esters (GC-FAME). Technical Note 101. Newark, DE: MIDI. - 2006. 
60. Sathiyaseelan K., Saranraj P. Antagonistic activity of marine actinobacteria - a review // Indo - Asian Journal of Multidisciplinary Research. - 2016. - V. 2, № 4. - P. 698-717.

61. Sayed A. M., Hassan M. H. A., Alhadrami H. A., Hassan H. M., Goodfellow M., Rateb M. E. Extreme environments: Microbiology leading to specialized metabolites // J. Appl. Microbiol. - 2020. - V. 128. - P. 630-657. doi: 10.1111/jam.14386

62. Shaala L. A., Youssef D. T. A., Alzughaibi T. A., Elhady S. S. Antimicrobial chlorinated 3-phenylpropanoic acid derivatives from the Red sea marine actinomycete Streptomyces coelicolor LY001 // Mar Drugs. - 2020. - V. 18, № 9. - P. 1-12. https://doi. org/10.3390/md18090450

63. Shirling E. B., Gottlieb D. Methods for characterization of Streptomyces species // International Journal of Systematic and Evolutionary Microbiology. - 1966. - V. 16. - P. 313-340.

64. Silva L. J., Crevelin E. J., Souza D. T., Lacerda-Junior G. V., Oliveira V. M., Ruiz A. L. T. G. et al. Actinobacteria from Antarctica as a source for anticancer discovery // Scientific Reports. - 2020. - V. 10. - P. 1-15. doi: 10.1038/s41598-020-69786-2

65. Solan M., Whiteley N. Stressors in the Marine Environment: Physiological and Ecological Responses / Societal Implications, 2016. - Oxford: Oxford University Press. - P. 70-79.

66. Subramani R., Aalbersberg W. Marine actinomycetes: An ongoing source of novel bioactive metabolites // Microbiol. Res. - 2012. - V. 167. - P. 571-580.

67. Subramani R., Aalbersberg W. Culturable rare actinomycetes: Diversity, isolation and marine natural product discovery // Appl. Microbiol. Biotechnol. - 2013. - V. 97. - P. 9291-9321.

68. Subramani R., Sipkema D. Marine Rare Actinomycetes: A Promising Source of Structurally Diverse and Unique Novel Natural Products // Marine Drugs. - 2019. - V. 17, № 249. P. 1-35. doi: 10.3390/md17050249

69. Sun W., Zhang F., He L., Karthik L., Li Z. Actinomycetes from the South China Sea sponges: isolation, diversity, and potential for aromatic polyketides discovery // Front. Microbiol. - 2015. - V. 6. - P. 1-15. https://doi.org/10.3389/fmicb.2015.01048 
70. Tenebro C. P., Trono D. J. Von L., Vicera C. V. B., Sabido E. M., Ysulat J. A., Macaspac A. J. M. et al. Multiple strain analysis of species from Philippine marine sediments reveals intra species heterogeneity in antibiotic activities // Scientific reports. -2021 . - V. 11. - P. 1-14. https://doi.org/10.1038/s41598-021-96886-4

71. Terahara T., Naemura T., Nampo Y., Kobayashi T., Imada C., Hamada M. et al. Streptomyces otsuchiensis sp. nov., a biosurfactant-producing actinobacterium isolated from marine sediment // Int. J. Syst. Evol. Microbiol. - 2019. - V. 69 - P. 3740 3744. doi 10.1099/ijsem.0.003638

72. Tuttle R. N., Demko A. M., Patin N. V., Kapono C. A., Donia M. S., Dorrestein P. et al. Detection of natural products and their producers in ocean sediments // Appl. Environ. Microbiol. - 2019. - V. 85. - P. 1-15. https://doi.org/10.1128/AEM.0283018

73. Ulfah M., Kasanah N., Handayani N. S. N. Bioactivity and genetic screening of marine Actinobacteria associated with red algae Gelidiella acerosa // Indonesian Journal of Biotechnology. - 2017. - V. 22, № 1. - P. 13-21. https://doi.org/10.22146/ ijbiotech. 25920

74. Vasyurenko Z. P., Frolov A. F. Fatty Acid composition of bacteria as a chemotaxonomic criterion // J Hyg Epidemiol Microbiol Immunol. - 1986. - V. 30, № 3. - P. 287-293.

75. Velasco-Alzate K. Y., Bauermeister A., Tangerina M. P., Lotufo T. M. C., Ferreira M. J. P., Jimenez P. C. Marine bacteria from Rocas Atoll as a rich source of pharmacologically active compounds // Marine Drugs. - 2019. - V. 17. - P. 1-16. https:// doi.org/10.3390/md17120671

76. Vicente J., Stewart A., Song B. Hill R. T., Wright J. L. Biodiversity of actinomycetes associated with caribbean sponges and their potential for natural product discovery // Mar. Biotechnol. - 2013. - V. 15. - P. 413-424.

77. Wang S., Zhou Y., Zhang G. Nocardioides flavus sp. nov., isolated from marine sediment // Int. J. Syst. Evol. Microbiol.- 2016. - V. 66. - P. 5275-5280. doi: 10.1099/ijsem.0.001507

78. Ward A. C, Bora N. Diversity and biogeography of marine actinobacteria // Curr. Opin. Microbiol. - 2006. - V. 9. - P. 279-286. 
79. Welch D. F. Applications of cellular fatty acid analysis // Clin. Microbiol. Rev. - 1991. - V. 4. - P. 422-438.

80. Yan C., Xue Q., Chen Z.-Q., Zhang R. Classification and Salt-tolerance of Actinomycetes in the Qinghai Lake Water and Lakeside Saline Soil // Journal of Sustainable Development. 2009. - V. 2, № 1. - P. 107-110. doi:10.5539/JSD.V2N1P107

81. Yang-Mei Z., Bai-Lian L., Xin-Heng Z., Xiao-Jun H., Hong Y. L., Ying Z. Anandins A and B, Two Rare Steroidal Alkaloids from a Marine Streptomyces anandii H41-59 // Marine drugs. - 2017. - V. 15, № 11. - P. 1-9. doi: 10.3390/md15110355

82. Yanti A. H., Setyawati T. R., Kurniatuhadi R. Composition and Characterization of Actinomycetes Isolated from Nipah Mangrove Sediment, Gastrointestinal and Fecal Pellets of Nipah Worm (Namalycastis Rhodhocorde) / A. H. Yanti, T. R. Setyawati, R. Kurniatuhadi // International Conference of Mangroves and Its Related Ecosystems: abstract book: OP Conf. Series: Earth and Environmental Science. - 2019. - P. 1-11. doi:10.1088/1755-1315/550/1/012003

83. Yi H., Schumann P., Sohn K. Chun J. Serinicoccus marinus gen nov., sp. nov., a novel actinomycete with 1-ornithin and 1-serine in the peptidoglycan // International J. Syst. Evol. Microbiol. 2004. - V. 54. - P. 1585-1589. 